\title{
Sosyal Medyada Kurumsal Kimlik: Türk Finans Sektöründeki Sosyal Ağlar Üzerine Bir Analiz
}

\author{
Zekiye Beril AKINCI VURAL* Aslı SAYAT ${ }^{* *}$ Duygu ÇAVUŞ***
}

ÖZET

Günümüz dijital çağında yaşanan değişim ve dönüşümler, insanlar arasındaki iletişim süreçlerinin de değişmesine sebep olmaktadır. Bu durum kurumların da hedef kitleleriyle iletişime geçme yöntemlerindeki değişimleri beraberinde getirmektedir. Yaşanan bu değişimler kurumsal kimliğin yansıtılacağı sanal ortamları ortaya çıkarırken diğer yandan kurumsal iletişim süreçlerinin geçmişe kıyasla daha kolay yönetilmesine olanak sağlamaktadır. Bu süreçte, bankacılık sektörü gibi rekabetin yoğun olduğu pazar ortamlarında kurumlar fark yaratıp kurumsal kimliklerini hedef kitleye aktarma süreçlerinde sosyal medya ortamlarını kullanmaktadır. Bu çalışmada da bankacılık sektöründe faaliyet gösteren kurumların kimliklerini sosyal medya üzerinden nasıl aktardıklarının ortaya konulması amaçlanmaktadır. www.boomsocial.com sitesinde yer alan "Brands Top 100" listesindeki verilere göre finans sektöründe önde gelen iki markanın (Ziraat Bankası, Garanti Bankası) Facebook, Instagram ve Twitter hesapları ele alınmıştır. Örneklem olarak seçilen bankaların sosyal medya hesapları iki farklı model esas alınarak oluşturulan kodlama tablolarıyla 1-30 Kasım 2017 tarihleri arasında analiz edilmiştir. Elde edilen bulgular çerçevesinde, Ziraat Bankası sosyal medyada kurumsal kimliğini daha etkin şekilde yansıtırken Garanti Bankası'nın ise tüketiciyle birebir iletişime geçmede daha aktif bir profil sergilediği sonucuna ulaşılmaktadır.

Araştırma Makalesi

Geliş: 05.08.2020

Kabul: 29.12.2020

Anahtar Kelimeler:

Sosyal Medya,

Kurumsal Kimlik,

Bankalar,

Finans Sektörü

\section{Corporate Identity On Social Media: An Analysis of Social Networks In Turkish Financial Sector}

\section{ABSTRACT}

Research Article

Developments and transformation in digital age cause major changes in communication processes among people. This situation also brings forth related changes in the communication processes of corporations with their target audiences. While those changes reveal virtual environments to represent the corporate identity, they also provide an opportunity that manage the corporate communication processes more easily than ever. Within in the competitive market environments, as in the banking sector, corporations try to make good use of social media in order to differentiate themselves and transfer corporate identity to their target audiences. The aim of this study is to discover how corporations transmit their identities via social media in the banking sector. The official social media accounts of the two banks in Turkey (Ziraat and Garanti) were approached according to "Brands Top 100" list of www.boomsocial.com website. Social media accounts of the selected sample banks were analysed between 1 and 30 November in 2017 with coding tables based on two different models. Depending on the findings of the research, Ziraat Bank has been found more successful in reflecting its corporate identity via social media while Garanti Bank has been found more effective in communicating with its consumers through personal communication.

Received: 05.08.2020

Accepted: 29.12.2020

Keywords:

Social Media,

Corporate Identity,

Banks,

Financial Sector.

* Prof.Dr., Ege Üniversitesi, İletişim Fakültesi, Kurumsal İletişim Anabilim Dalı, z.beril.akinci@ege.edu.tr, ORCID ID: https://orcid.org/0000-0002-5078-4339

** Ege Üniversitesi, Sosyal Bilimler Enstitüsü, Kurumsal İletişim Yüksek Lisans Programı, aslisayat@gmail.com, ORCID ID: https://orcid.org/0000-0002-5078-4339

*** https://orcid.org/0000-0002-5078-4339Ege Üniversitesi, Sosyal Bilimler Enstitüsü, Kurumsal İletişim Yüksek Lisans Program1, cavusduygu92@gmail.com, ORCID ID: https://orcid.org/0000-0002-5078-4339 


\section{GíRIŞ}

Günümüz rekabet koşullarında kurumlar, kurumsal kimliklerini aktararak pazarda yer alan diğer kurumlardan kendilerini farklılaştırıp, hedef kitlenin zihninde yer etmeye çalışmaktadır. Bu durum yaşanan dönemin özelliklerine göre değişip şekillenmektedir. 1970'lerde başlayıp 1990'lardan sonra hızla devam eden internet kullanımı 2000'li yıllarda sosyal medyanın işlerlik kazanmasıyla neredeyse her insanı ilgilendirecek noktalara varmaktadır. Dijital dünyada yaşanan bu gelişmeler hedef kitlenin büyük bir çoğunluğunun aktif bir şekilde sanal ortamlarda yer almasına olanak sağlamaktadır. Bu doğrultuda sanal ortamlarda her geçen gün daha fazla konumlanan hedef kitlenin farkına varan kurumlar, iletişim faaliyetlerini sosyal medya alanlarına kaydırmaya başlamıştır. Sosyal medyada daha aktif şekilde var olmaya çalışan kurumlar, kurumsal kimlik algısını artık bu alanlar üzerinden de yönetmektedir.

Yaşadığımız dönemde sosyal medyanın doğru kullanımı etkili kurum kimliğinin temel noktası olarak görülmektedir. Sürdürülebilirlik için kurumlar yeni iletişim ortamlarından yararlanırken kimliklerini pazarda stratejik şekilde konumlandırıp, kalıcı olmasını sağlamaktadır. Yeni ortamlara uyum sağlamayan kurumların uzun vadede etkin olması mümkün görülmemektedir. Kurumlar için son derece önemli olan bu konunun aktarımının nasıl yapıldığını incelemek amacıyla yapılan bu çalışmanın ilk bölümünde sosyal medya, kurumsal kimlik ve sosyal medyada kurumsal kimlik üzerine literatür araştırması yapılmıştır. İkinci bölümde finans sektöründe bulunan iki markanın sosyal ağları üzerine bir analiz yapılıp, son bölümde ise kurumların kurumsal kimlik çalışmalarını sosyal medya üzerinden nasıl aktardıklarına dair bir sonuca ulaşılmaya çalışılmıştır.

\section{SOSYAL MEDYA}

Yeni bir medya olan sosyal medya kavramının ortaya çıkışı Web 2.0 teknolojisi ile doğrudan ilişkilidir. "Web 2.0" terimi birçok şekilde ele alınıp, Google'da çok sayıda alıntı yapılmış olmasına rağmen terimin tanımı hakkında net bir kanıya varılamamaktadır. Bazı alan uzmanları bunu klişeleşmiş bir pazarlama kelimesi olarak reddetmekte; bazı alan uzmanları ise yeni bir akıl olarak kabul etmektedir ${ }^{1}$. Web 2.0 daha spesifik olarak kullanıcı topluluğunun uzmanlığından yararlanan bloglar, wiki'ler, RSS beslemeleri, eşler arası ağlar, bilgi ve enformasyon sistemleri ile ilgilenmektedir. Web 2.0'ın kurumdaki kullanımı, kullanıcı tarafından sahip olunan ve yönetilen güçlü bir bilgi yönetim sistemi oluşturmak için bilgi paylaşımındaki bu iş birliğine dayalı sosyal ağları kullanmakta veya birleştirmektedir. Söz konusu teknolojiler bilgi yaratma ve düzenleme konusundaki kullanıcı katkılarına geleneksel yaklaşıma göre daha çok vurgu yapmaktadır. Bloglar, wikiler, sosyal ağlar gibi

\footnotetext{
${ }^{1}$ Tim O'Reilly (2007), "What Is Web 2.0: Design Patterns and Business Models for the Next Generation of Software", International Journal of Digital Economics, C.65, S.1, s.18.
} 
kurumsal kültür ve kimlik üzerinde etkili olan Web 2.0 ortamları kurumun güçlü kaynakları haline gelerek esnek iş tasarımları için yenilikçi fikirler önermek üzere yeni iş modelleri yaratmaktadır. Web 2.0 teknolojileri, bilgisayar iletişiminin iş uygulamalarında temel bir noktaya geldiğinden daha fazla önem kazanmaktadır². Bu teknolojiye geçen kurumların özellikleri; düşük maliyetli hizmetlerden yararlanma, daha fazla insanın kullanmasıyla daha çok zenginleşen benzersiz ve yeniden oluşturulması zor veri kaynaklarını kontrol etme, güvenilir kullanıcılar yaratma, ortak akıl geliştirme, uzun kuyruk gücü oluşturma ve farklı iş modelleri olarak sıralanmaktadır ${ }^{3}$.

Geleneksel medyada pasif tüketici konumunda olan kullanıcılar Web 2.0 teknolojisi ile daha aktif bir konuma gelerek içerik üretmeye başlamıştır. Web 2.0 sayesinde kullanıcılar fikirlerini diğer kullanıcılar ile paylaşabilmekte ve geribildirimde bulunabilmektedir. Günümüzde çoğu kişi kendisine gönderilen mesaja güvenmeme eğilimi göstermektedir. $\mathrm{Bu}$ doğrultuda kurumlar, kullanıcılarla iletişime geçme yöntemlerinde değişiklik yapmaya yönelmektedir. Eskiden kurumlar kullanıcıya yansıtmak istediği imaj doğrultusunda iletişimlerine yön vermekte iken, Web 2.0 ile birlikte kurumlar, tam kontrolü kaybetmektedir. Kurumlar kullanıcıların kendileri ile ilgili algılarını öğrenebilmek için onlarla diyaloğa geçmek durumundadır ${ }^{4}$. Bu doğrultuda kurumların kullanıcılara ulaşmak için kullandıkları geleneksel halkla ilişkiler stratejileri Web 2.0'ın gelişmesiyle etkisini yitirmekte ve kurumlar bu teknolojik gelişmelere adaptasyon sağlamaktadır. Aksi halde yeniliklere ve kullanıcıların istek ve beklentilerine uyum sağlayamayan kurumların uzun vadede başarılı olabilmeleri mümkün olamamaktadır.

Kurumların iş modellerini değiştiren ve yaratıcı stratejiler gerektiren Web 2.0'ın getirdiği yeni bir medya olan sosyal medyanın bazı tanımları aşağıda yer almaktadır:

- Sosyal medya Web 2.0 teknolojisine dayanan, farklı coğrafyalardan kişi veya kurumların amaçları doğrultusunda içerik üreterek paylaştıkları ve geri bildirim alabildikleri, kullanıcıların kontrol sahibi olmalarına izin veren çevrimiçi uygulamalardır ${ }^{5}$.

- Sosyal medya kavramı insanların birbirleriyle karşılıklı bilgi, fikir ve ilgi duydukları konuları paylaşarak etkileşim kurmalarına olanak sağlayan çevrimiçi araçlar ve web sitelerini içermektedir6́.

\footnotetext{
${ }^{2}$ Greg Hearn, Marcus Foth ve Heather Gray (2009), "Applications and Implementations of New Media in Corporate Communications: An Action Research Approach", Corporate Communications: An International Journal, C. 14 S. 1 , s.51. ${ }^{3}$ Tim O'Reilly, a.g.m., ss.36-37.

${ }^{4}$ Hilal Özdemir Çakır (2016), Sosyal Medyada Kurumsal İtibar Yönetimi, İstanbul: Kriter Yayınevi, s.17.

${ }^{5}$ Z. Beril Akıncı Vural, Mikail Bat (2014), "Yeni Bir Medya Olarak Sosyal Medyanın Genel Çerçevesi”, Edt: Z. Beril Akıncı Vural, Dijital Panorama Bilgi İletişim Teknolojilerinde Son Gündem, Ankara: Ütopya Yayınevi, s.101.

${ }^{6}$ Elif Korap Özel (2014), "Çalışanların Twitter Kullanımının Kurum İmajına Etkisi: Türkiye’de Bir Anket Çalışması”, Journal of Yasar University, C.9, S.35, s.6140.
} 
Sosyal medya terimi üzerine yapılan tanımlara bakıldığında bazı ortak vurgular dikkat çekmektedir. İçerik, kullanıcılar tarafindan oluşturulup sosyal içerikli web sitelerinde herkese açık olarak paylaşılmaktadır. $\mathrm{Bu}$ doğrultuda kullanıcılar haber, fotoğraf, video gibi kendi içeriklerini oluşturmaktadır ve bu çevrimiçi uygulamalar da katılıma, karşılıklı paylaşıma, yoruma ve beğeniye açık olmaktadır ${ }^{7}$. Geleneksel medyada izleyici ve okuyucular sadece tüketen konumunda bulunmaktadır. Sosyal medya, kullanıcıları pasif içerik okuyucularından içerik üreticilerine dönüştürerek rollerini daha önemli hale getirmektedir ${ }^{8}$. Bu durumda sosyal medya geleneksel medyanın karşılayamadığı ihtiyaçları karşılamakta ve yeni bir medya olarak eksiklikleri gidermektedir.

Bilgisayar ve mobil iletişim araçlarıyla erişilen internet üzerindeki sosyal medya; e-posta grupları, bloglar (ilgi alanlarına göre; nilerturk.net), forumlar (Forumtr, Donanımhaber, Shiftdelete), kurumsal intranet (kurum için ağ), extranet (kurumsal müşterilere açılan ağ), hızlı mesaj servisleri (Msn, Skype), sosyal ă̆ siteleri (Facebook, Twitter, Instagram, Youtube, Swarm) olarak birkaç grupta toplanmaktadır ${ }^{9}$. Sosyal ağ siteleri sanal bir ortamda sosyal etkileşimi teşvik etmek için tasarlanmıştır. İletişim, profilde yayınlanan bilgiler aracılığı ile kolaylaştırılmakta, genellikle kullanıcıların fotoğraflarını ve kendi ilgi alanlarını açıklayan kişisel bilgileri içermektedir. Bunlar kullanıcıların kimliği ile ilgili bilgi sağlamaktadır. Buna ek olarak kullanıcılar diğer kullanıcıların da profillerini görebilmekte ve e-mail, chat gibi araçlar ile iletişime geçebilmektedir ${ }^{10}$. Bu doğrultuda yeni bir çevrimiçi ortam olarak sosyal medyanın özellikleri 5 başlıkta açıklanmaktadır ${ }^{11}$ :

- Katılım: Sosyal medya, istekli olan herkesi katk1 yapma ve geri bildirim konusunda cesaretlendirmektedir.

- Açıklık: Sosyal medya servisleri geribildirime ve katılıma açıktır. Bu servisler oylama, yorum ve bilgi paylaşımı gibi konulara teşvik etmektedir. Erişime yönelik engeller çok nadir olarak koyulmaktadır.

- Konuşma: Geleneksel medyanın merkezinde yayın olmasına karşılık, sosyal medya çift yönlü konuşmaya açık olmaktadır.

\footnotetext{
${ }^{7}$ Yeşim Güçdemir (2017), Sosyal Medya Halkla İlişkiler, Reklam ve Pazarlama, İstanbul: Derin Yayınları, s.15.

${ }^{8}$ Alton Y.K Chua, Snehasish Banerjee, (2013) "Customer Knowledge Management via Social Media: the Case of Starbucks", Journal of Knowledge Management, C.17 S.2, s.239.

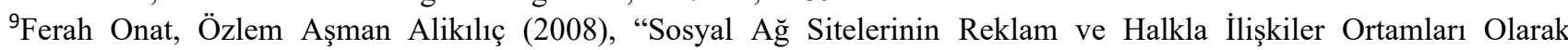
Değerlendirilmesi”, Journal of Yasar University, C.3, S.9, s.1118.

${ }^{10}$ Tiffany A. Pempek, Yevdokiya A. Yermolayeva, Sandra L. Calvert (2009), "College Students' Social Networking Experiences on Facebook", Journal of Applied Developmental Psychology, C.30, S.6, s.228.

${ }^{11}$ Antony Mayfield (2008), “What is Social Media?”, http://www.icrossing.com, Erişim Tarihi: 31.10.2017.
} 
- Topluluk: Sosyal medya topluluklara hızlı ve etkili bir haberleşme için izin vermektedir. Kullanıcılar sevdikleri fotoğraflar, politik görüşler, favori TV şovları gibi ortak ilgi alanlarını paylaşmaktadır.

- Bağlantılılık: Sosyal medyanın çoğu türü, bağlantılı işler gerçekleştirmektedir. Diğer sitelere, araştırmalara ve insanlara link verilmesini sağlamaktadır.

Sosyal medya hem fırsatlara hem de tehditlere zemin hazırladığı için kurumlardaki iş düzenini değiştirmektedir. Kuruma çeşitli faydalar sağlamakla birlikte tehditler de yaratabilmektedir. Olumlu açıdan bakıldığında ilk olarak kurum ile paydaşları arasında etkin ve karşılıklı ilişki kurmayı, onları dinlemeyi ve isteklerine yanıt vermeyi geçerli kılmaktadır. İkinci olarak kurumların paydaşları tarafından oluşturulan gerçek zamanlı verilere erişmesini, paydaşları hakkında bilgi aramasını ve ürün/hizmetleri hakkında geri bildirim almasını sağlamaktadır. Üçüncü olarak paydaşlar kendi soruları olabilecek diğer paydaşların kurum tarafından yanıtlanmış sorularını görebildiklerinden, sosyal medya kurumlar için düşük maliyetli bir iletişim yolu olmaktadır. Diğer yandan sosyal medya kurum için tehditler de yaratmaktadır. Sosyal medya paydaşlara kurum hakkındaki düşüncelerini yüksek hızda ifade edebilecekleri bir ortam yaratmaktayken kurum, kendileri hakkında söylenen görüşleri kontrol etmekte daha az güce sahip olmaktadır. Kurumun sosyal medya araçlarındaki bu kontrol eksikliği kurumun savunmasızlığını arttırarak krizlerin sıklığının ve şiddetinin artmasına da sebep olmaktadır ${ }^{12}$. Sosyal medyanın kurumsal krizlere zemin hazırlaması, kurumları kurumsal iletişim stratejilerini yeniden planlamaya teşvik etmektedir. Sosyal medya doğru yönetilebildiğinde kurum için tehdit oluşturmaktan çok yarar sağlamaktadır. Kurum ve çalışanlara birçok avantaj yaratan sosyal medya, sohbetlerin farklı forumlara iletilebilecek konuşmalar anlamına gelen "uzun kuyruk" kavramını kullanarak daha geniş bir kitleye ulaşmasını sağlamaktadır. Bir kurumda toplantılar, telefon görüşmeleri ve e-postalar içeren birkaç iletişim kanalı kullanılmaktadır. Bu iletişim kanallarının, bir mesajı unutmak, bir toplantı sırasında not almayı kaçırabilmek ve zorlayıcı olabilecek büyük bir epostalar listesinde bilgi aramak gibi kendi sınırlamaları bulunmaktadır. Sosyal medya, kurumun ekip üyeleri arasındaki iş birliğini geliştirdiğinden daha iyi iş sonuçları alınmaktadır. İnsanların fikir üretmesine ve paylaşmasına olanak sağlayan bir role sahip olan sosyal medya, ekibin genel etkinliğini arttırmaktadır. Kurumlar, iyi yapılandırılmış bir sosyal profilleri olduğunda, çalışanlarının iletişim ağlarından yararlanmasına izin verme eğilimi göstermektedir. Bu durum, çalışanların sektördeki son gelişmelerle güncel kalmasına ve üst düzey liderlerle bağlantıda olmasına yardımcı olmaktadır.

\footnotetext{
12 Mina Roshan, MatthewWarren, RodneyCarr, (2016), "Understanding the Use of Social Media by Organisations for Crisis Communication”, Computers in Humor Behavior, C.63, s.351.
} 
Çalışanlarla yönetim arasında açık iletişimi desteklemektedir. Bu açık iletişim ile çalışanların proje fikirlerini paylaşmasına, etkin ekip çalışmasına, deneyim ve bilgi paylaşmalarına olanak sağlamaktadır. Sosyal medya basit metinlere göre web cast ve videolar gibi daha iyi içeriği teşvik etmektedir. Buna ek olarak mevcut ve potansiyel müşteri ile kurum arasında iş birliğine dayalı iletişim kurmaya, geri bildirim almaya, ürün tanıtımı ya da her türlü müşteri hizmetlerine destek çıkmaya yardım etmektedir. Bu doğrultuda çalışanları kurumun bir parçası olmak adına cesaretlendirmektedir. Günümüzde sosyal medya, tartışmalar için iyi bir ortam olarak pazarlama ve iletişimin bir amacı haline gelmektedir. Kurum bu avantajları yönetebilmek için çalışanlarının sosyal medya kurallarına ve etik ilkelerine bağlı kalmasını garanti altına almaktadır ${ }^{13}$. Sosyal medyanın dinamik yapısı kurumlara herhangi bir davranıştan dolayı beklenmedik bir anda kriz getirebileceği için, sosyal medyayı bir avantaj olarak yöneten kurumlardaki çalışanlar etik ilkelere uymaktadır.

Kurumsal iletişim etkinliklerinin altında yürütülen bir iletişim disiplini olarak gelişen sosyal medya yönetimi, kurumsal iletişimin hedeflerine uygun olarak belirli sosyal medya ortamlarının kullanılması ve bu ortamların diğer iletişim ortamları ile koordinasyonunun gerçekleştirilmesini ele almaktadır ${ }^{14}$. Kullanıcıların birbirleriyle ve kurumlarla olan iletişimini paylaşım sınırı koymadan gerçekleştiren bir ortam olan sosyal medya, birey ve kurumlara özgür bir tartışma ortamı yaratmaktadır. Buna ek olarak marka ve kurum konumlandırmasına, kurumsal itibarın artmasına yardım ederek kurumsal kimliği desteklemektedir ${ }^{15}$. Bu doğrultuda sosyal medya yönetiminin iş modellerindeki yeri değişmekte olup, kurumsal kimlik stratejisinde önemi artmaktadır.

\section{KURUMSAL KIMLIKK KAVRAMI VE KAPSAMI}

Kimlik, insana has bir kavram olarak bilinmektedir. Kimlik, insanı diğerlerinden farklı kılan ve onu benzersiz, kıyaslanamaz yapan bir nitelik taşımaktadır. Kurum kimliği kavramı ise kişisel kimlikten farklı olarak bir kurumun kim olduğunu, ne yaptığını belirtmektedir. Kurumlar birer kimlik oluşturarak aslında kendilerine özgü ortak ilke ve olgular oluşturmaktadırlar. Böylece her kurum kendisini diğerlerinden farklılaştırarak kurum içinde bütünlüğü sağlarken, diğer yandan da hedef kitlelerin zihinlerinde yer bulmaktadır ${ }^{16}$. Kurum kimliği, kurumun fiziksel anlatımı olmakla beraber kurumun, iletişim tarzını ve itibarını korumak için ortaya konan davranışla anlatılan kültürün bir parçası olarak

\footnotetext{
${ }^{13}$ Simeon Edosomwan, Sitalaskshmi Kalangot Prakasan, Doriane Kouame, Jonelle Watson, Tom Seymour (2011), "The History of Social Media and its Impact on Business", The Journal of Applied Management and Entrepreneurship, C.16, S.13, ss.85-89.

${ }^{14}$ Korhan Mavnacıŏlu (2015), Kurumsal İletişimde Sosyal Medya Yönetimi Kurumsal Blog Odaklı Bir Yaklaşım, İstanbul: Beta, s.73.

${ }^{15}$ Gonca Telli Yamamoto, Özgür Karamanlı Şekeroğlu (2014), Sosyal Medya ve Blog, İstanbul: Kriter Yayınevi, s.11.

${ }^{16}$ F. Bahar Ülker Kaya (2006). “Kurum Kimliği ve Kurumsal Tasarım”, Tasarım+Kuram Dergisi, Sayı:4, s.27.
} 
gösterilmektedir. Kurumun kişiliğini belirtmektedir ve onu diğerlerinden farklı k1lmaktadır ${ }^{17}$. Günümüzde kurumlar, aynı sektörde çok fazla kurumun olması, iletişim ve erişimin eskiye oranla daha hızlı gerçekleşmesi ile artan rekabetçi yapıda kendilerini daha etkin şekilde hedef kitleye tanıtabilmek, kalıcı olabilmek ve farklarını sergileyebilmek için kurumsal kimlik çalışmalarına önem vermeye başlamışlardır ${ }^{18}$.

Kurumsal kimlik, her kurum için gereklilik sayılmaktadır. Logo, kurum tasarımı gibi kavramlar genelde kurumsal kimlik olarak bilinmektedir. Oysa kurumsal kimlik logo, reklam, iç ve diş iletişim, kurum imajı, kurum itibarı hakkında bilinenden çok daha fazlasını kapsamaktadır ${ }^{19}$. Kurumsal kimlik kurumun ifade edilmesinin, açıklanmasının temel noktası olarak görülmektedir. Kurumun her anlamda tanıtımını (sözlü, görsel vb.), diğer kurumlar arasındaki konumlandırmasını ve pazar rekabeti içindeki her düzeyde farklılaştırmayı kapsamaktadır. Bu sebepten kavram, kurumun etkinlik tarzları ve izlediği stratejilerle doğrudan bağlantılı sayılmaktadır ${ }^{20}$.

Kurum kimliğinin oluşturulmasıyla halkla ilişkiler uzmanları ilgilenmektedir. Çünkü kurum kimliği, kurumun yansıyan tüm görüntüsünü içermektedir. $\mathrm{Bu}$ doğrultuda iletişimin büyük ve önemli bir noktasının sembolü olarak görülmektedir. Kurum kimliği yalnızca pazarlama ve reklamcılıkla değil, çalışan ekiple, hedef kitleyle, satın alanlarla, tüketenlerle ve finansal ilişkilerle de ilgili olmaktadır ${ }^{21}$. Ürün ve hizmetler haricinde kurumun bir tanımlaması olan kurumsal kimlik çalışmaları, kurumun kim olduğunu, neler yaptığını ve bunları yaparken nasıl bir yol izlendiğini gösteren çalışmaları kapsamaktadır. Bunun yanında ürün ve hizmetler, içte ve dişta bulunan hedef kitleler, iletişim ve davranış tarzları ile de doğrudan ilgilidir ${ }^{22}$.

\section{Kurumsal Kimliğin Bileşenleri}

Kurumsal kimliğin bileşenlerini kurum felsefesi, kurumsal davranış, kurumsal iletişim, kurumsal imaj ve kurumsal kültür başlıkları altında incelemek mümkün görülmektedir. Kurum felsefesi, kurumun değer ve yargılarından, hedeflerinden ve tarihçesinden oluşmaktadır. Kurumsal davranış bir yandan çalışanların hedef kitleye karşı tutumlarını kapsarken diğer yandan çalışanların kurumla bütünleşme etkinliklerini kapsamaktadır. Kurumsal iletişim ise kurumun hedefleri adına sürekliliğini

\footnotetext{
17 , (y.y), “What is Corporate Identity and Why Is It Important?”, www.treefrog.ca, Erişim Tarihi: 14.11.2017.

18 Abdulgani Arıkan, (2017), "Kurumsal Tasarım ve Görsel Kimlik”, (Edt: Başak Solmaz), Kurumsal İletişim, Eskişehir: Anadolu Üniversitesi Basımevi, s.75.

${ }^{19}$ Z. Beril Akıncı Vural, Mikail Bat (2013), Teoriden Pratiğe Kurumsal İletişim, İstanbul: İletişim Yayınları, s.87.

20 Zeliha Hepkon (2003). "Kurumsal Kimlik İnşasını Belirleyen Faktörler: Bir Literatür Taraması", İstanbul Ticaret Üniversitesi Dergisi, Sayı:9, s.179.

${ }^{21}$ Frank Jefkins (1995). "Kurum Kimliği”, Çev: Okay Aydemir, Marmara İletişim Dergisi, Sayı:9, s.33.

${ }^{22}$ Z. Beril Akıncı Vural (1998), Kurum Kültürü ve Örgütsel İletişim, İstanbul: İletişim Yayınları, s.179.
} 
gerçekleştirmek için kurumu oluşturan tüm bölüm veya kurum ile çevresi arasında, devamlı fikir alışverişini mümkün kılan sosyal bir alan yaratmaktadır ${ }^{23}$.

Kurumsal imaj kısaca insanlar tarafından algılanan şekliyle kurumsal kimlik olarak ifade edilmektedir. Kurumsal kimliğin ve kurumsal imajın uyumu kurumun etkinliklerini içtenlikle sergilemesi ile mümkün olmaktadır. Yalnızca bunun gerçekleştirilmesi yetersiz kalacağı için kurumun tanıtımını etkili ve gerçekçi yapması, bu sayede istenen görüntüyü zihinlere yerleştirmesi gerekmektedir ${ }^{24}$. Kurumsal imaj kavramı kurumsal kimlik ile karıştırılan bir kavram olmasına rağmen kurumsal imaj, kurumun mantıksal olarak nasıl hareket ettiği ile kurumsal kimlik ise kurumun dıştan nasıl tanındığ ile ilgili olmaktadır. Kurumsal kimliğe sahip olunup olunmadığını, kurumsal kimlik ile kurumsal imajın farkının bilinip bilinmediğini kurumların kendilerine sorması gerekmektedir ${ }^{25}$.

Kurum kültürü ise bir kurumun bünyesindeki işleyişi belli çizgilerle sürdürerek kuruma kişilik kazandıran soyut bir kavramdır ve çalışma biçiminden, kutlamalara kadar çok geniş bir alanı kapsamaktadır. Kurumlar da toplumlar gibi değerlerini, normlarını, hedeflerini yansıtan nitelikler göstermektedir. Bu inanç, anlayış ve kuralların tümü kurum kültürünü oluşturmaktadır ${ }^{26}$.

Kurumsal kimlik ve kurumsal kültür alanındaki çalışmalar kurum içindeki çalışanların çalışma isteğini yükseltme ve kurumlarına karşı bağlılık yaratma ilkesine dayanmaktadır. Böylece çalışanlar kurumlarını daha iyi tanırken diğer yandan da kurumunu dışarıya daha iyi tanıtmaktadırlar. Kurumsal kültür ve kurumsal imaj, kurumsal kimlik ile iç içe olan ama ayrı tutulan kavramlar olarak görülmektedir. Bir kurum oluşturmayı istediği kurum kimliği doğrultusunda bir kurum kültürü yaratabilmektedir ${ }^{27}$.

Kurumlar aktarmak istedikleri kimlik ile orantılı olarak kültürlerini de inşa etmektedir. Kurum kültürü, kurum kimliği bileşenlerine göre düzenlenen bir alan olarak görülmektedir. Kurum kültürü, çalışanların kurum ile birleşmesini, adaptasyonunu sağlamaktadır. Ortak değer ve takım ruhu yaratarak çalışanlarını organize etme ve şekillendirme görevini üstlenmektedir. Kurumsal kültür, çalışanları isteklendirirken kurum hakkındaki görüşlerini pozitif yöne çevirip etkileşimli bir iletişim düzeni sağlamaktadır ${ }^{28}$.

\footnotetext{
${ }^{23}$ Mehmet Enes İnce, “Kurumsal Kimlik”, www.kto.org.tr, Erişim Tarihi: 19.11.2017.

${ }^{24}$ Mehmet Tığlı (2003). "Kurum İmajı Kavramı ve Sembolik Anoloji Tekniği Yoluyla Marmara Üniversitesi’nin Kurum İmajının Belirlenmesine İlişkin Bir Uygulama”, T.C Marmara Üniversitesi İ.̇̇.B.F. Dergisi, Cilt: XVIII, Sayı:1, s.246.

${ }^{25}$ Mustafa Karadeniz (2009). "The Importance of Creating a Successful Corporate Identity and Corporate Image for Enterprises in Marketing Management”, Journal of Naval Science and Engineering, Cilt:5, Say1:3, s.3.

${ }^{26}$ Orhan Erdem, Metin Dikici (2009). "Liderlik ve Kurum Kültürü Etkileşimi”, Elektronik Sosyal Bilimler Dergisi, Cilt:8, Say1:29, s.205.

${ }^{27}$ Sevil Uzoğlu (2001). “Kurumsal Kimlik, Kurumsal Kültür ve Kurumsal İmaj”, Kurgu Dergisi, Say1:18, s.351.

${ }^{28}$ F. Bahar Ülker Kaya, a.g.m., s.29.
} 


\section{Kurumsal Kimliğin Hedef ve Yararları}

Değişen toplum koşulları kurumsal kimlik kavramının da değişmesine, içeriğinin genişlemesine sebep olmaktadır. Kurumsal kimlik kavramı genelde görsel tasarım olarak ele alınırken 1970’lerden itibaren kurum felsefesi, kurumsal davranış, kurumsal tasarım gibi ögeler de kurumsal kimlik kavramının altında yer almaya başlamıştır. Bu ögelerin en önemli noktalarından biri de görsel kimlik olarak görülmektedir. Kurumun logosundan renklerine kadar görsel ögeleri kapsayan görsel kimlik, kurum kimliğini anlatmakta yeterli olmasa da ilk etapta kurumu tanıtıcı bir görev üstlenmektedir. Doğru konumlandırılmış görsel kimlik, kurumu doğru tanıtırken, kurum kimliğini de sağlamlaştırmaktadır ${ }^{29}$. Kurum kimliği altında yer alan görsel kimliğin dört tane hedefi vardır. Bunlardan ilki isme bir şahsiyet kazandırarak kuruma hayat vermektir. İkincisi; kurumun kabul edilmesini ve hatırlanmasını yaygınlaştırmaktır. Üçüncüsü; kurumun rekabet ortamında diğerlerinden farklı olmasına, sivrilmesine yardımcı olmaktır. Dördüncüsü ise farklı kurum unsurlarını fikir ve duygu birliği içerisinde birbiriyle kaynaştırmaktır ${ }^{30}$.

Kurumsal kimlik kavramı üzerine yapılan araştırmalar, kurumun dışarıdan nasıl göründüğünü betimleyen; başkalarının "başta çalışanların” kurumu ne durumda bulduklarına dair görüşlerinin önemine işaret etmektedir. Kurumun amaçlarını gerçekleştirmek için temelde çalışanların taleplerini göz önünde bulundurmak gerektiği vurgulanmaktadır ${ }^{31}$. Kurumsal kimlik, yalnızca paketi değil, içinde bulunduğu ürünü ve onu destekleyen hizmeti de hesaba katmaktadır. Sadece üniforma değil, kurum için çalışan insanların kendileri hakkında düşünme biçimini ifade etmektedir ${ }^{32}$.

Kurumsal kimlik, kurumun kendisini kitlelere ifade etme tarzı, kurumun toplumda betimlenen tarafi olarak görülmektedir. Bu betimlenen tarafın çizgileri belirlenmiş olup sık sık değişikliğe uğramamakla birlikte kurum da çizilen bu imajı değiştirmek istememektedir. Kurumsal kimlik bir anlamda kurumun imzası, sembolü olduğu için büyük değişikliklere genellikle açık olmamaktadır ${ }^{33}$.

\footnotetext{
${ }^{29}$ Banu Baskan Karsak (2008). "Web Sitelerinin Kurumsal Kimlik Açısından Değerlendirilmesi: En Beğenilen 20 Şirket Üzerine Bir Analiz”, İleti-ş-im, Sayı:9, s.168.

${ }^{30}$ Perry A., Wisnom D. (2003), Markanın DNA’sı - Eşsiz Ve Dayanıklı Markalar Yaratmanın Kuralları, İstanbul: Mediacat Yayınları'ndan aktaran Gülay Öztürk (2006). “Logonun Kurum Kimliği Üzerindeki Etkisi”, İstanbul Ticaret Üniversitesi Sosyal Bilimler Dergisi, Cilt:5, Sayı:9, s.8.

${ }^{31}$ Selma Karatepe (2008). "İtibar Yönetimi: Halkla İlişkilerde Güven Yaratma”, Elektronik Sosyal Bilimler Dergisi, Cilt:7, Say1:23, s.82.

32 Wally Olins, (2003), “Corporate Identity: The Myth and The Reality”, (Edt: John M. T. Balmer, Stephen A. Greyser), Revealing the Corporation, Londra: Routledge, s.64.

33 Ayşen Akbaş Tuna (2007), Kurumsal Kimlik Yönetimi, Ankara: Detay Yayıncılık’tan aktaran Ali Asker Atam (2014). "Kurumsal Kimlik Çalışmaları: Beko Örneği”, The Turkish Online Journal of Design, Art and Communication, Cilt:4, Sayı:2, s.18.
} 


\section{Kurum Kimliğinin Kurum Açısından Önemi}

Etkili bir kurum kimliği, etkili bir markanın yaratılmasının temel noktası sayılmaktadır. Marka, kurumsal unsurları açısından kalite ve güven gibi ögeleri hedef kitlesine iletmektedir. Kurumsal kimliğin marka tarafından doğru kullanımı ile kurum, tanıtım çalışmalarının sağlayacağı yarardan daha çoğunu elinde bulundurabilmektedir. Etkili bir kurumsal kimlik oluşturulması markanın simgelenmesi noktasında da büyük değer taşımaktadır ${ }^{34}$. Hedef kitle, kurum üzerine olan algılarının değiştirilmesini etkili bir kurumsal kimlik ile bağdaştırmaktadır. Güçlü bir kurumsal kimlik, hedef kitlenin bağlılığını oluşturmakla yetinmeyip, alıcı temelini artırıp, yeni alıcılar oluşturmaktadır ${ }^{35}$.

Rekabetin giderek arttığı günümüz toplumlarında kurumlar, kendilerini diğerlerinden farklılaştırarak üstünlük kazanma eğilimindedir. Bu noktada kendi içlerinde dengeli, geçerli ve birbirini tamamlayan felsefe, tutum ve eylemler ortaya koymaktadırlar. Kurum, kurum kimliği adı altında toplanan bu unsurlarını kurumsal iletişim biçimleri dolayısıyla içte ve dışta bulunan hedef kitlelerine benimseterek etkili bir kurumsal imaj oluşturmaya çaba göstermektedir ${ }^{36}$. Bu doğrultuda bugünün toplumlarında değerli olarak görülen nokta, evrensel rekabetin çizdiği pazar şartlarında, farklı olmak için bütün görsel kimlik ögelerini değerlendirerek; ayırt edilebilir, biricik, yaratıcı ve yalnızca "görüntüsü için bile" seçilebilecek kurum, marka ve ürünlerin ortaya konması olmaktadır ${ }^{37}$.

\section{KURUMSAL KIMLİK VE SOSYAL MEDYA}

Günümüzde enformasyon teknolojilerinde yaşanan gelişmeler, insanlar arasındaki iletişim süreçlerinin değişmesine sebep olmaktadır. Bu durum da kurumların insanlarla iletişime geçme stratejilerindeki değişimleri beraberinde getirmektedir. Yaşanan teknolojik değişimlerin sonucunda, yer ve zaman kavramları önemini yitirmekte, geri bildirim ve etkileşime olanak sağlayan platformlar ortaya çıkmaktadır. İnternet ve bilgi teknolojilerindeki değişim ve dönüşüm ile birlikte, kurumsal iletişim geçmişe kıyasla daha kolay bir hal almakta, bunun nezdinde kurum kimliğinin yansıtılacağı sanal ortamlar da çoğalmaktadır ${ }^{38}$.

Kurumsal kimliğin bileşenleri rehberliğinde oluşturulan kimlikler, geleneksel yöntemler yerine sosyal medya ortamları üzerinden iç ve dış paydaşlara aktarılmaya çalışılmaktadır. Çünkü kurumlar

\footnotetext{
${ }^{34}$ Telha Er, Kurumsal Kimlik Oluşumunda Kültürün Etkisi; Arçelik’in Kurum Kimliği, T.C İstanbul Arel Üniversitesi Medya ve Kültürel Çalışmalar Anabilim Dalı Yayınlanmamış Yüksek Lisans Tezi, İstanbul, 2016, s.34.

35 Meena Azzollini, (2016), “What is Corporate Identity and Why is it Important?”, www.linkedin.com, Erişim Tarihi: 05.11.2017.

${ }^{36}$ M. Kazım Sezgin (2008). "İletişim Biçimi ve Ortamı Olarak Görsel Kimlik”, Selçuk İletişim, Cilt:5, Sayı:2, s.61.

${ }^{37}$ Z. Beril Akıncı Vural, Rana Kesken (2012). "Rekabet Avantajı Sağlanmasında Kurumsal Pazarlama ve Kurumsal Görsel Kimlik”, Erciyes İletişim Dergisi, Cilt:2, Sayı:4, s.72.

${ }^{38}$ Cristina Castronovo, Lei Huang (2012), "Social Media in an Alternative Marketing Communication Model”, North American Business Press, Cilt:6, Say1:1 s._.
} 
açısından, artan rekabet ortamlarında hedef kitlenin dikkatini çekebilmek, düşük maliyetli ve etkili mesajlar iletebilmek için sosyal medya ortamları cazip bir seçenek olarak ortaya çıkmaktadır ${ }^{39}$.

Dijital çağa evrilen günümüz koşulları, kurumsal kimlik kavramının genişlemesine neden olmaktadır. Bu durum kurumsal kimlik kavramının sadece geleneksel yöntemlerle değil, aynı zamanda sosyal medya üzerinden yönetilmesi ihtiyacını da doğurmaktadır. Kapsamı genişleyen kurumsal kimlik kavramının en önemli noktalarından biri olarak görülen görsel kimlik de kendini en etkin bir şekilde sosyal medyada ifade edebilme olanağı bulmaktadır. Sosyal medyada doğru yapılandırılmış görsel kimlik, kurum kimliğini de sağlamlaştırma görevi görmektedir. Burada dikkat edilmesi gereken nokta, geleneksel yöntemlerle yönetilen kurumsal kimlikle, sosyal medyada yönetilen kurumsal kimliğin birbiri ile örtüşmesidir. Sosyal medyanın doğru kullanımı etkili kurum kimliğinin temel noktası olarak karşımıza çıkmaktadır. Etkili sosyal medya stratejileri, hedef kitlede bağlılık oluştururken, yeni alıcıların ortaya çıkmasını sağlamaktadır. Aynı zamanda, hedef kitlenin büyük bir çoğunluğu sosyal medya ortamlarında zaman geçirmekte, burada tartışmalar ve paylaşımlar gerçekleştirmektedir. $\mathrm{Bu}$ bağlamda, sosyal medya, kurumların birey ile arasında herhangi bir araç olmadan iletişime geçebileceği ortamlar olarak ortaya çıkmaktadır. Ayrıca, kurumlara hedef kitle ile iletişim kurmak ve onlara çevrim içi ve çevrim dışı ortamlarda kimliklerini teyit ettirme fırsatı sunmaktadır ${ }^{40}$. Tüm bunlar dikkate alındığında, kurumlar yaratıcı stratejilerle sosyal medya ortamlarını kullanarak kendi kültürel değerlerini hedef kitleye aktarabilmektedir. Diğer bir ifadeyle, kurumsal temsilciler kurumun kimliğini oluşturmak, doğrulamak ve pekiştirmek için sosyal medya platformlarından yararlanmaktadır. Çünkü kurumlar, değişen hedef kitle özelliklerinin en doğal ve yalın haliyle geri yansıyabileceği en işlevsel iletişim ortamlarından biri olan sosyal medya ortamlarının faydalarını gün geçtikçe daha fazla görmektedir $^{41}$. Bu bağlamda kurumlar sosyal medyada bulunma süreçlerini etkili yönetip, aktif bir şekilde var olduklarında, kendileri hakkında oluşan algıyı yönetebilme imkânına sahip olmaktadır.

Tüm bunların nezdinde kurumlar tarafindan etkin bir sosyal medya kullanımı ${ }^{42}$ :

- Kurum ile paydaşlar arasında etkin ve karşılıklı ilişki kurma imkânı vermekte ve paydaşları dinleyip isteklerine yanıt verme imkânı sunmaktadır.

\footnotetext{
${ }^{39}$ Mehmet Tokatlı, İbrahim Özbükerci, Nazan Günay, Beril Akıncı Vural (2017), "Kurumsal İtibarın Sosyal Medya Üzerinden Aktarımı: Sektör Liderlerinin Twitter Yönetimi Üzerine Bir Araştırma”, Gümüşhane Üniversitesi İletişim Fakültesi Elektronik Dergisi, Cilt:5, Sayı:1, s.40.

40 Ali Fikret Aydın (2012), "Kurumsal İtibar Açısından Sosyal Medyaya İlişkin Değerlendirme”, Karadeniz Teknik Üniversitesi İletişim Araştırma Dergisi, Sayı:9, s.86.

${ }^{41}$ Ali Fikret Aydın, a.g.m., s.86.

42 Mina Roshan, Matthew Warren, Rodney Carr, (2016), ''Understanding the Use of Social Media by Organisations for Crisis Communication', Computers in Humor Behavior, C.63, s.351, ss.350-361.
} 
- Kurumların, paydaşlar tarafından oluşturulan gerçek zamanlı verilere erişmesine, paydaşlar hakkında istediği zaman verilere ulaşabilmesine, oluşturulan kurumsal kimlik hakkında geri bildirim alınmasına olanak sağlamaktadır.

Kimliğin bileşenlerini oluşturan kurum felsefesi, kurumsal davranış, kurumsal iletişim, kurumsal imaj ve kurumsal kültür, sosyal medyada da yansıtılması gereken noktalardır. Sosyal medya bu konuların betimlenmelerini kolaylaştırırken diğer yandan da zorlukların doğmasına sebep olmaktadır. Geleneksel medyada kurumlar, yansıtmak istediklerini halkla ilişkiler uzmanları aracılığıyla ve kendi istedikleri iletişim tarzlarıyla iletmekteydi. Fakat günümüzde sosyal medyanın önemli bir güç olması ile birlikte kurumlar, ellerinde bulundurdukları kontrolü kaybetmeye başlamıştır. Bu bağlamda sosyal medyanın, hedef kitleye kurum hakkındaki düşüncelerini özgürce ifade edebileceği ortamlar sunmasının yanında, kurumun kendisi hakkında ifade edilen görüşlerini kontrol etmekte eskiye oranla daha az güce sahip olduğu görülmektedir. Böyle bir ortamda da krizlerin ortaya çıkma ihtimali çoğalmaktadır. Krizler, sosyal medya ortamlarında hızlıca ve aniden yayılabildiği için kurumların hedef kitle ve paydaşlarıyla olan iletişimlerinde hız ve şeffaflığın önemi giderek artmaktadır. Sosyal medya ortamlarının anlık olarak takip edilmesi ve etkileşimlere hızlı bir şekilde geri dönülmesi bu önemin bir göstergesi olmaktadır. Şeffaflığa ve hıza dayalı kurumsal iletişim stratejileri kurumsal kimliği yansıtan bir unsur haline gelmiştir.

Sonuç olarak, kurumlar sürdürülebilir ve planlı bir yaklaşımla hedef kitle nezdinde farklılaşmak, etkin ve karşılıklı ilişki kurma imkânı elde etmek için yeni iletişim ortamlarından yararlanarak sosyal medya araçlarını kullanmaktadır. Bu doğrultuda kurumlar, öncellikle sosyal medya ortamlarında sanal kurumsal kimliklerini oluşturmalı ve pekiştirmelidir. Daha sonra oluşturulan kimliklerin pazarda konumlandırılması, kabul görmesi ve kalıcı olması sağlanmalıdır ${ }^{43}$. Aksi halde yeniliklere, kullanıcıların istek ve beklentilerine uyum sağlayamayan kurumların, uzun vadede başarılı olabilmelerinin mümkün olmadığı dile getirilmektedir.

\section{TÜRK FİNANS SEKTÖRÜNDEKİ SOSYAL AĞLAR ÜZERINE ANALIZZ}

\section{Araştırmanın Amacı ve Sorunsalı}

Sosyal medya, günümüzde birçok alan için büyük değer taşımaktadır. Dünya grafiklerine bakıldığında Türkiye, bilgi iletişim teknolojilerini aktif kullanan ülkeler arasında yer almaktadır ${ }^{44^{*}}$. Bu nedenle farklı sektörlerden kurum ve kuruluşlar işlemlerini sanal ortama aktarmakta ve hedef kitlelerini bu

\footnotetext{
43 Gülay Öztürk (2006), "Logonun Kurum Kimliği Üzerindeki Etkisi”, İstanbul Ticaret Üniversitesi Sosyal Bilimler Dergisi, Cilt:5, Say1:9, s.8.

44* www.boomsocial.com
} 
platformlarda yakalamaya çalışmaktadır. Ancak kurumların resmi kimlikleri ile bu platformlarda olmaları hedef kitlelerin algıları açısından da büyük değer taşımaktadır. Finans sektörü gibi çoğunlukla dijital işlemlerin görüldüğü kurumlarda bu konuyla ilgili birçok örneğe rastlanmaktadır. Bu doğrultuda çalışmanın amacı; Türk finans sektöründe faaliyet gösteren kurumların resmi kimlikleriyle sosyal ağlarında nasıl yer aldıklarını tespit etmektir. Çalışmanın sorunsalı ise "aynı sektörde bulunan farklı kurumların, kurumsal kimlikleri arasındaki benzerliklerinin neler olduğudur”.

\section{Araştırmanın Evreni, Örneklemi ve Kısıtlılıkları}

$\mathrm{Bu}$ çalışmanın evreni, www.boomsocial.com sitesindeki "Brands Top 100" listesinde bulunan 100 markadan oluşmaktadır. Ölçüt örneklem yöntemi kullanılarak alınan çalışmanın örneklemi ise bu listede finans sektörü üzerinden düşünüldüğünde ilk 10'da bulunan 2 markadır. Bunlar sırasıyla Ziraat Bankası (6. sırada) ve Garanti Bankası'dır (9. sırada). Çalışmanın kısıtlılığı ise boomsocial.com sitesindeki markaların ele alınması, Brands Top 100'deki ilk 10 sıradaki finans markalarının değerlendirilmesi ve bu listenin Kasım 2017 verilerini kapsamasıdır.

\section{Araştırmanın Modeli}

$\mathrm{Bu}$ çalışmada, ele alınan bankaların sosyal ağlarının incelenmesinde karşılaştırmalı betimsel analiz yapılmıştır. Ele alınan sayfaları betimlemek için içerik analizi tekniği kullanılmıştır. Bu doğrultuda; Gibson, Margolis, Resnick ve Ward'un (2001) “Election Campaigning On The WWW In The US And The UK: A Comparative Analysis" adlı çalışmasında kullandıkları model esas alınmıştır. Söz konusu model iki ana başlıkta toplanmaktadır. Bilgi akışı, kaynak toplama, haberleşme ağı, katılımcılık ve kampanya gibi fonksiyonları ile incelenmiştir. Daha sonra ise web siteleri, görsellik, erişebilirlik, gezilebilirlik ve görülebilirlik gibi sunum özellikleriyle değerlendirilmiştir. Ancak ilgili model Bat'ın “Dijital Platformda Sosyal Medyanın Stratejik Kurumsal İletişime Etkisi” (2012) başlıklı, 425261 sayılı doktora tezinde sosyal ağlara adapte edilerek kullanılmıştır. Bu çalışmada da modelin orijinal hali ve Bat'ın tezindeki adapte edilmiş hali ele alınarak son bir model oluşturulmuştur.

\section{Veri Toplama Araçları}

$\mathrm{Bu}$ araştırma kapsamında ele alınan iki bankanın sosyal medya hesapları ve web siteleri dijital doküman incelemesi ile nitel veri toplama yöntemi kullanılarak yapılmıştır. Araştırma kapsamında öncelikle incelemede kullanılacak temalar belirlenmiştir ve bu temalar çerçevesinde sosyal ağların incelemesi yapılmıştır. Bilgiler, söz konusu bankaların sosyal ağlarına araştırmacıların kişisel sosyal ağları üzerinden katılım gerçekleştirilerek elde edilmiştir. 


\section{Veri Toplama Süreci}

Araştırma sürecinde ele alınan bankaların sosyal ağları incelenmiştir. Sosyal ağların incelenmesinin ardından bazı temalar belirlenmiştir. Temel alınan modelin temaları ele alınarak kıyaslama yapılıp toplam sonuca ulaşılmıştır. Araştırmacılar farklı bankaların sosyal ağlarını incelemiştir, ardından birbirlerinin incelediği sosyal ağları gözden geçirmiştir. Araştırmacılar son aşamada bir araya gelerek verileri toplu olarak değerlendirmişlerdir. Veri analizinde tablolarda Facebook (F), Twitter (T) ve Instagram (I) şeklinde kısaltılmıştır.

\section{Veri Analizi}

\section{Kurumsal bilgi akışı}

Tablo 1. Bankaların Kurumsal Bilgi Akışı

\begin{tabular}{|c|c|c|c|c|c|c|}
\hline \multirow{2}{*}{ Kurumsal Bilgi Akışı } & \multicolumn{3}{|c|}{ Ziraat Bankası } & \multicolumn{3}{c|}{ Garanti Bankası } \\
\cline { 2 - 7 } & F & T & I & F & T & I \\
\hline Kurumun Tarihçesi & 1 & 0 & 0 & 1 & 0 & 0 \\
\hline Kurumun Amacı & 0 & 0 & 0 & 1 & 0 & 0 \\
\hline Kurumun Ilkeleri & 0 & 0 & 0 & 1 & 0 & 0 \\
\hline Kurumsal Vizyon & 0 & 0 & 0 & 0 & 0 & 0 \\
\hline Kurumsal Misyon & 1 & 0 & 0 & 0 & 0 & 0 \\
\hline Kurumsal Reklamlar & 1 & 1 & 1 & 1 & 1 & 1 \\
\hline Etkinlikler/Duyurular & 1 & 1 & 1 & 1 & 1 & 1 \\
\hline Basınla İlişkiler/Basın Odası & 1 & 1 & 1 & 1 & 1 & 1 \\
\hline (Bültenler, haberler vb.) & 1 & 0 & 1 & 1 & 1 & 1 \\
\hline Ürün/Hizmet Bilgileri & 1 & & 1 & & & 0 \\
\hline
\end{tabular}

\section{Ziraat Bankası'nın kurumsal bilgi akışı}

Kurumun Facebook ağında; tarihçesine ilişkin bilgiler detaylı olarak verilmiştir. Bu ağda "hakkında" bölümünde kuruluş yılı bilgisi verilmiş, "kilometre taşları" adlı bölümde ise kurumun tarihçesi detaylandırılmıştır.

Twitter hesabında kapak fotoğrafındaki görsel ile bankanın 154. yılı olduğu aktarılmaktadır. (Aynı görsel Facebook hesabının da kapak fotoğrafı görselidir) Ancak kurumun tarihçesine ilişkin bu bilginin dışında detaylı bilgiye rastlanmamaktadır. Twitter'ın 280 karakterlik sosyal ağ yapısı dikkate 
alındığında tarihçeye ilişkin ayrıntılı bilgilerin verilmesi mümkün görülmemektedir. Ancak sayfada verilen www.ziraatbank.com.tr linki ile ayrıntılı tarihçeye ulaşılmaktadır.

Instagram ağında ise Twitter'da bulunan 154. yıl görseli paylaşılmıştır, bunun dışında kurum tarihçesine ait başka bir bilgi verilmemiştir. Ancak Twitter'da olduğu gibi web sitesine yönlendirme bulunmakta ve ayrıntılı kurum tarihçesine oradan ulaşılabilmektedir.

Kurumun amacı ile ilgili bilgilere, ayrıntılı bir şekilde hiçbir sosyal ağda rastlanmamaktadır. Amaca ait bilgiler, paylaşılan görsellerde ve videolarda dolaylı olarak yer almaktadır. Kurum tarihçesinde olduğu gibi kurum amacı ile ilgili bilgilere de kurumun web sitesinden ulaşmak mümkündür.

Kurumsal misyon bilgisi sadece Facebook ağında "hakkında" bölümünde bulunmaktadır. Bu bilgiye üç sosyal ağ profilinde de yer alan kurum web sitesi linki üzerinden ulaşmak mümkündür.

Kurumsal reklam üç sosyal medya hesabında da eş zamanlı olarak yayınlanmaktadır. 17.11.2017'de yayınlanan video " $\mathrm{Bu}$ ülkenin hep daha fazlası için çalışan insanlarının yanında daha fazlasını yapmaktan hiç vazgeçmeyen bir Ziraat var” başlıklı bir 154. yıl reklamıdır. Reklam videosu Facebook ve Twitter' da direkt olarak paylaşılırken, Instagram'da 154. y1l görseli altında "reklam filmimizi profil linkimize tıklayarak izleyebilirsiniz" başlığıyla paylaşılmıştır. Instagram'ın sadece 60 saniyelik video yüklemeye uygun olan sosyal ağ yapısı göz önüne alındığında 86 saniyelik bu reklamın direkt olarak paylaşılması mümkün görülmemektedir.

Ayrıca üç sosyal ağda da bu reklam videosu \#vazgeçemezsin, \#ZiraatBankası, \#BirBankadanDahaFazlası, \#ZiraatBankası154Yaşında hashtagleri ile paylaşılmıştır. Tüm paylaşımlarda genellikle \#ZiraatBankası hashtagi kullanıldı ̆̆ı dikkat çekmektedir.

Etkinlikler/duyurular, kurumsal reklamlar da olduğu gibi üç sosyal ağda eş zamanlı olarak yayınlanmaktadır. Etkinlik paylaşımları fotoğraflarla, duyuru paylaşımları ise görsellerle desteklenmektedir. Bu etkinlik ve duyuruların başlıkları şu şekildedir:

- KYK kredi/burs hesabınıza ait Bankkart Genç'inizi teslim alabileceğiniz tarihleri ve Şubeyi/Teslim Noktasını T.C. kimlik numaranız ile https://kyksorgu.ziraatbank.com.tr adresinden öğrenebilirsiniz. (16.11.2017)

- $\quad$ KYK'dan ilk defa kredi/burs alacak öğrenciler için kredi/burs ödemeleri TCKN son hanesine göre 27.11.2017-01.12.2017 tarihleri arasında gerçekleştirilecektir. (27.11.2017)

- $\quad$ Ziraat Türkiye Kupası 5. tur maçlarıyla devam ediyor! (28.11.2017)

- Antalya Growtech Eurasia Uluslararası Sera, Tarım Ekipmanları ve Teknolojileri Fuarı'nda çiftçilerimizin yanındayız. (30.11.2017) 
Özellikle duyuru amaçlı yapılan paylaşımların metinlerine kurumun web sitesinin "duyurular" başlığına yönlendiren bir link eklenmesi dikkat çekmektedir.

Basınla ilişkiler başlığı altında inceleyebileceğimiz içerikler şunlardır:

- Ekonomist Dergisi tarafından bu yıl 26. sı düzenlenen "Ekonomide Yı1ın İş İnsanları" araştırmasında Genel Müdürümüz Sayın Hüseyin Aydın "Y1lın Bürokratı” seçildi. (06.11.2017)

- “Türkiye'nin Lovemark'ları 2017” araştırması sonucuna göre bankamız, bankacılık kategorisinde bu yıl da Türkiye'nin en sevilen bankası seçilmiştir. Hep birlikte gönüllerde bir iz bırakıyor olmamızın gururunu sizlerle paylaşmaktan mutluluk duyuyoruz. (07.11.2017)

- $\quad$ Türkiye'nin en sevilen Bankası olarak Brand Week İstanbul'dayı. (08.11.2017)

- Lovemarks 2017 araştırmasına göre Türkiye'nin en sevilen bankası Ziraat Bankası. Gönülleri kazanmak hep daha fazlasını ister. (09.11.2017)

$\mathrm{Bu}$ içerikler kurumun tüm sosyal ağlarında eş zamanlı ve video, fotoğraf, görsellerle desteklenerek yayınlanmaktadır. Tüm bu içerikleri etkinlikler ve duyurular başlı̆ğ altında değerlendirmek de mümkündür.

Ürün/hizmet bilgileri kurumun Facebook ağında "hakkında" bölümünde "finans şirketi, finans hizmeti banka", Instagram ağında "finnans şirketi” şeklinde tanımlanmaktadır. Twitter ağında ise bu tür bir bilgiye rastlanmamaktadır.

Kurumun ilkeleri ve vizyonu ile ilgili bilgiler, hiçbir sosyal ağda bulunmamaktadır. Bu bilgilere kurumun web sitesi üzerinden ulaşmak mümkündür.

\section{Garanti Bankası'nın kurumsal bilgi akışı}

Kurumun Facebook ağında; tarihçesi, amacı ve ilkelerine ilişkin bilgiler "hakkında" bölümünde "şirkete genel bakış" başlığı altında kısaca yer verilmiştir.

Twitter ve Instagram hesaplarında ise; tarihçesine, amacına ve ilkeleri hakkında hiçbir veriye rastlanmamıştır. Fakat Twitter ve Instagram'ın ağ yapısı dikkate alındığında bu maddelerle ilgili ayrıntılı bilgilerin verilmesi mümkün görülmemektedir. Ancak kurumun Twitter ağında yer alan www.garanti.tr linkinden kurumunu tarihçesine, amacına ve ilkeleriyle ilgili bilgilere ulaşabilmek mümkündür.

Kurumun vizyonu ve misyonuna ait bilgilere hiçbir sosyal ağda rastlanmamıştır. Ancak Facebook ve Twitter'da linki bulunan kurumun web sitesinde "Garanti' yi Tanıyın” başlığı altında vizyon ve misyon bilgilerine ulaşmak mümkündür. 
Kurumun sosyal ağlarında basınla ilişkilerle ilgili içerikler bulunmaktadır. Bunlar;

- $\quad$ Twitter, "Mutluyuz bizi, Türkiye'nin en sevilen mobil bankası seçen tüm kullanıcılarımıza sonsuz teşekkürler.” (08.11.2017)

- $\quad$ Twitter, "Mutluyuz Interactive Media Awards 2017 ödüllerinde, bankacılık kategorisinde en iyi web sitesi garanti.com.tr seçildi.” (14.11.2017)

- $\quad$ Facebook, "Mutluyuz Interactive Media Awards 2017 ödüllerinde, bankac1lık kategorisinde en iyi web sitesi, www.garanti.com.tr seçildi. Sizi de www.garanti.com.tr “ye bekleriz.” (14.11.2017)

- Twitter, "Ekonomi Bakanlığı ve Kagider tarafından düzenlenen 2. Kadın Girişimciler Konferansı'nda, Genel Müdür Yardımcımız Cemal Onaran, kadın girişimciliğinin bankamızdaki temel taşlarını ve kadın girişimcilere sağladığımız finansal olanakları anlattı.” (17.11.2017)

- Twitter, "Dönüşüme Liderlik ana teması ile 26.sı düzenlenen Kalite Kongresi kapsamındaki panele katılan GMY'miz Ebru Dildar Edin, Türkiye'nin sürdürülebilir kalkınmasındaki öncü rolümüze ve bunun sektördeki önemine değinen bir konuşma yaptı.” (21.11.2017)

- Twitter, “CDP Su Programı'nda Global A Listesi'ne giren dünya genelindeki tek finans kuruluşu olma başarısını gösterdiğimiz için mutluyuz.” (28.11.2017)

- Son olarak da Facebook sayfasında, "The Banker tarafından "Türkiye'de Yılın Bankası" seçildik! Yıllardır Garanti'ye güvenen, bu ödülü kazanmamızı sağlayan müşterilerimize ve çalışanlarımıza teşekkür ederiz.” (30.11.2017)

- Instagram sayfasında ise, aynı ifade ile paylaşım yapılmış ve kurumun renklerini içeren bir görsel ile içerik desteklenmiştir. (30.11.2017)

Paylaşılan içerikler incelendiğinde, duyurular eş zamanlı olarak paylaşılmamış, kimi zaman sadece Twitter'dan bilgilendirilme yapılırken, kimi zaman da hem Twitter'dan hem de Facebook'tan aynı içerik farklı şekilde ifade edilerek yayınlanmıştır. Burada sosyal ağların kendi yapılarına ve söylem dillerine uygun içerik üretilmesi dikkat çekmektedir. Ayrıca, tüm bu içerikleri etkinlikler ve duyurular başlığı altında değerlendirmek de mümkündür.

Kurumsal reklam başlı̆̆ı üç sosyal medya hesabında da eş zamanlı olarak yayınlanmaktadır. 03.11.2017'de yayınlanan “Ugi'den Barış ve Kerem'i şaşırtan hareketler.” başlıklı video bir reklam kampanyasıdır. Ayrıca video sosyal ağların tümünde \#barışugikerem hastagleri ile paylaşılırken, Instagram ağı üzerinde reklamda yer alan Kerem Bursin ve Barış Arduç’un hesapları etiketlenmiştir. 
Ürün/hizmet bilgileri kurumun Facebook ağında "hakkında" bölümünde "finans şirketi”, Instagram ağında "finans şirketi” şeklinde tanımlanmaktadır. Twitter ağında ise bu tür bir bilgiye rastlanmamaktadır.

\section{Kullanım bilgileri ve görsel aktarımı}

Tablo 2. Bankaların Kullanım Bilgileri ve Görsel Aktarımı

\begin{tabular}{|c|c|c|c|c|c|c|}
\hline \multirow{2}{*}{ Kullanım Bilgileri ve Görsel Aktarımı } & \multicolumn{3}{|c|}{ Ziraat Bankası } & \multicolumn{3}{c|}{ Garanti Bankası } \\
\cline { 2 - 7 } & F & T & I & F & T & I \\
\hline Kurumsal Rengin Kullanımı & 1 & 1 & 1 & 1 & 1 & 1 \\
\hline Slogan & 0 & 1 & 1 & 1 & 1 & 1 \\
\hline Logo/Amblem & 1 & 1 & 1 & 1 & 1 & 1 \\
\hline Video/ Animasyon/ Gif & 1 & 1 & 1 & 1 & 1 & 1 \\
\hline Sosyal Ağlar Kısa Yol Girişi & 1 & 0 & 0 & 0 & 1 & 0 \\
\hline Ana Web Site Linki & 1 & 1 & 1 & 1 & 1 & 0 \\
\hline
\end{tabular}

\section{Ziraat Bankası'nın kullanım bilgileri ve görsel aktarımı}

Kurumsal renkler kurum tarafından yazılı olarak aktarılmamıştır. Kurum logosundan yola çıkarak kurumsal renklerin kırmızı ve beyaz olduğu bilgisine ulaşılmaktadır. Üç sosyal medya ağında da kurumsal renkler kullanılmaktadır.

Kurumun "bir bankadan daha fazlası" sloganı Twitter ve Instagram ağlarında bulunurken Facebook ağında bulunmamaktadır.

Kurumun logosu üç sosyal ağın da profil görseli olarak kullanılmaktadır. Kampanya, özel gün, duyuru görsellerinde logo kullanılırken kurum içinde çekilen fotoğraflarda ve etkinlik fotoğraflarında kullanılmamaktadır.

Kurumun üç sosyal ağında da içerikler video ve animasyonlarla desteklenmektedir.

Kurumun sadece Facebook ağında Ziraat Twitter ve Ziraat YouTube butonları vardır. Twitter ve Instagram ağlarında sosyal ağlar kısa yol girişine rastlanmamaktadır.

Kurumun ana web site linki üç sosyal ağda da yer almaktadır. 


\section{Garanti Bankası'nın kullanım bilgileri ve görsel aktarımı}

Kurumsal renkler kurum tarafından yazılı olarak aktarılmamıştır. Kurum logosundan yola çıkarak kurumsal renklerin yeşil ve beyaz olduğu bilgisine ulaşılmaktadır. Üç sosyal medya ağında da kurumsal renkler kullanılmaktadır.

Kurumun “başka bir arzunuz” sloganı sadece Instagram'da bulunurken, Twitter ve Facebook’ta sosyal sorumluluk için paylaşılan bir video içeriğinde slogan seslendirilmektedir.

Kurumun logosu, üç sosyal ağın da profil görseli olarak kullanılmaktadır. Ayrıca, kampanya, özel gün, duyuru içerikleri logo ve amblem kullanımıyla desteklenmektedir.

Kurumun sosyal ağlarının hepsinde, video ve animasyonlarla desteklenmektedir.

Kurumun Twitter hesabında "Garanti'ye Sor" adlı 7/24 destek vermek için oluşturulan Twitter hesabının linki bulunmaktadır. Ayrıca kurumun ana web site linki Facebook ve Twiter sosyal ağlarında yer alırken, Instagram'da link yer almamaktadır.

\section{Kurumsal iletişim hizmetleri}

Tablo 3. Bankaların Kurumsal İletişim Hizmetleri

\begin{tabular}{|c|c|c|c|c|c|c|}
\hline \multirow{2}{*}{ Kurumsal İletişim Hizmetleri } & \multicolumn{3}{|c|}{ Ziraat Bankası } & \multicolumn{3}{|c|}{ Garanti Bankası } \\
\hline & $\mathbf{F}$ & $\mathbf{T}$ & $\mathbf{I}$ & $\mathbf{F}$ & $\mathbf{T}$ & $\mathbf{I}$ \\
\hline Online Bankacılık / Mobil Erişim & 1 & 1 & 1 & 1 & 1 & 1 \\
\hline E-Posta ile Erişim & 0 & 0 & 0 & 0 & 0 & 0 \\
\hline $\begin{array}{l}\text { Sosyal Sorumluluk Kampanyalarının } \\
\qquad \text { Aktarımı }\end{array}$ & 0 & 0 & 0 & 1 & 1 & 1 \\
\hline $\begin{array}{c}\text { Ürün / Hizmet Kampanyalarının } \\
\text { Aktarımı }\end{array}$ & 1 & 1 & 1 & 1 & 1 & 1 \\
\hline $\begin{array}{l}\text { Belirli Hedef Kitleye Yönelik } \\
\text { Kampanya Duyuruları }\end{array}$ & 1 & 1 & 1 & 0 & 0 & 0 \\
\hline Diğer Kampanya Duyuruları & 0 & 0 & 0 & 0 & 0 & 0 \\
\hline Bilgilendirme İçeriği & 1 & 1 & 1 & 1 & 0 & 0 \\
\hline İnsan Kaynakları & 1 & 1 & 1 & 0 & 0 & 0 \\
\hline Müşteri Hizmetleri (Bize Ulaşın) & 1 & 0 & 1 & 1 & 1 & 0 \\
\hline Şube Noktaları & 0 & 0 & 0 & 1 & 0 & 0 \\
\hline S1k Sorulan Sorular & 0 & 0 & 0 & 1 & 0 & 0 \\
\hline Yardım Menüsü & 0 & 0 & 0 & 1 & 1 & 0 \\
\hline Yorumlara Cevap Verilmesi & 0 & 0 & 0 & 1 & 1 & 1 \\
\hline Her Gün Düzenli İçerik Üretimi & 0 & 1 & 1 & 0 & 0 & 0 \\
\hline
\end{tabular}




\section{Ziraat Bankası'nın kurumsal iletişim hizmetleri}

Kurumun üç sosyal ağında bulunan web sitesi linki online bankacılığa yönlendirmektedir. Aynı zamanda üç sosyal ağa mobilden erişim sağlanmaktadır.

Direkt olarak e-posta ile erişim hiçbir sosyal ağda bulunmamaktadır.

Kurumun hiçbir sosyal ağında 2017 Kasım ayında aktardığı bir sosyal sorumluluk kampanyasına rastlanmamaktadır.

Ürün/hizmet kampanyalarının aktarımı üç sosyal ağ üzerinden eş zamanlı olarak yapılmaktadır. 14.11.2017'de yayınlanan “Emeklinin, gençlerin, miniklerin, çalışanın artısı Ziraat'te. Daha fazlası için artılar Ziraat'te!” başlıklı görseli bu kategoride değerlendirmek mümkündür.

$\mathrm{Bu}$ görsel, Twitter ve Facebook ağında "detaylı bilgi için: http://www.ziraat.com.tr" ibaresiyle paylaşılmıştır. Instagram ağında ise "detaylı bilgiye internet sitemizden erişebilirsiniz" ibaresi yer almaktadır. Bunun sebebi Instagram'ın sosyal ağ yapısı ile ilişkilendirilmektedir. Instagram, görsellerin altına yazılan metinde web sitesi linki bulunduğunda direkt siteye yönlendirme yapmamaktadır. Linkin, direkt yönlendirme yapabilmesi için profilde bulunan web site bölümüne yazılması gerekmektedir. Kurumun Instagram profilinde web sitesi linki bulunmaktadır.

Ayrıca görsel üç sosyal ağda da \#ZiraatBankası hashtagi ile paylaşılmıştır. Instagram paylaşımlarında emoji kullanılmaması dikkat çekmektedir.

17.11.2017'de yine tüm sosyal ağlar üzerinden paylaşılan 154. yıl reklamını da ürün/hizmet kategorisinde değerlendirmek mümkündür.

Belirli hedef kitleye yönelik kampanyalar, kurumun üç sosyal ağında da eş zamanlı olarak paylaşılmaktadır. Öğrencilerin devlet burslarını aldığı banka olan Ziraat Bankası özellikle hedef kitlesinin öğrenciler olduğu kampanyaların aktarımını sosyal ağlar üzerinden görsellerle destekleyerek yapmaktadır. Hedef kitlesinin öğrenciler olduğu kampanyanın başlığı şu şekildedir: Öğrencinin dostu Bankkart Genç, hem banka kartı hem kredi kartı! (21.11.2017)

Hiçbir sosyal ağda diğer kampanya kategorisinde duyurumu yapılan herhangi bir kampanyaya rastlanmamaktadır.

03.11.2017'de üç sosyal ağda da eş zamanlı olarak yayınlanan “Ziraat Mobil QR Kod kullanın, kartsız para çekin, yatırın!” başlıklı görsel bilgilendirme içerikli paylaşım olarak değerlendirilebilmektedir. İçeriğin metninde kurumun web sitesinin “yeni nesil bankacılık ziraat mobil” başlıklı kısmına yönlendiren bir link bulunmaktadır. Sadece Instagram'da, ağın sosyal yapısı gereği link yerine “detaylı 
bilgiye internet sitemizden erişebilirsiniz" ibaresi bulunmaktadır. Bu içerikte tüm paylaşımlarda kullanılan \#ZiraatBankasi hashtagine ek olarak \#ZiraatMobil hashtagi de kullanılmıştır.

Ayrıca duyurular başlığı altında incelediğimiz içerikler de bilgilendirme içerikli paylaşım olarak kategorize edilebilmektedir. Bilgilendirme içeriklerinin hepsinde web siteye yönlendiren linkin de içerik metnine eklenmesi dikkat çekmektedir.

Instagram'da \#ÇalışanlarımızınGözündenTürkiye hashtagi ile çalışanların kendi memleketlerinden çektikleri fotoğrafların paylaşımı insan kaynakları başlığı altında değerlendirilmektedir. 04.11.2017'de Kayseri/ Belsin şubesinden Rasim Tekin'in çektiği fotoğraf, 05.11.2017'de kurumsal iletişim bölümünden Emre Külah'ın İstanbul'dan çektiği fotoğraf, 11.11.2017'de Bursa/ Hürriyet şubesinden Sercan Ok’un çektiği fotoğraf bu paylaşımlara örnek olabilmektedir.

Ayrıca Instagram'da “Bankamızın 154. yaşını gururla kutladık. Nice yaşlara hep birlikte. Bu ülkenin hep daha fazlası için çalışan insanlarının yanında daha fazlasını yapmaktan hiç vazgeçmeyen bir Ziraat var." başlığı ile Eskişehir, Elazığg, Diyarbakır ve Lefkoşa şubelerindeki çalışanların fotoğraflarının paylaşılması da bu kategori altında incelenmektedir. Genellikle tüm paylaşımların üç sosyal ağda da eş zamanlı olarak yapılmasına rağmen bu paylaşımların sadece Instagram'da yapılması dikkat çekmektedir.

Basınla ilişkiler ve etkinlikler/duyurular başlığı altında incelediğimiz içeriklerde paylaşılan ekip fotoğrafları da insan kaynakları başlığı altında değerlendirilmektedir. Bu başlıklar altında incelenen paylaşımlar üç sosyal ağda da eş zamanlı olarak yapılmaktadır.

Facebook ağında bulunan "bizimle iletişime geç" butonu web sitesi üzerinden iletişim formuna yönlendirmektedir. İletişim formunun bulunduğu kurum web sayfasının sağ alt köşesinde müşteri iletişim merkezi numarası paylaşılmaktadır. Diğer yandan “mesaj” butonu ile direkt kuruma mesaj göndermeye imkân tanınmaktadır. Twitter ve Instagram ağlarının yapısı gereği direkt mesaj gönderebilme olanağı bu ağlarda da mümkündür. Instagram ağında "ara" butonu bulunurken Twitter ağında bu tür bir iletişim butonuna rastlanmamaktadır.

Şubelerin bilgileri paylaşılmamakla birlikte \#TarihiŞubelerimiz hashtagi ile tarihi bazı şubelerin fotoğrafları eş zamanlı olarak üç sosyal ağ üzerinden de paylaşılmaktadır. 02.11.2017'de paylaşılan Konya/ Çumra şube fotoğrafı, 16.11.2017'de paylaşılan Çorum şube fotoğrafı bunlara örnek olabilmektedir. Şube noktaları bilgisine ise web sitesi üzerinden “en yakın Ziraat” bölümünden ulaşmak mümkündür.

S1k sorulan sorular bölümüne hiçbir sosyal ağda yer verilmemektedir. Ancak kurumun web sitesi üzerinden "sıkça sorduklarınız" bölümüne ulaşmak mümkündür. 
Yardım menüsü bölümüne hiçbir sosyal ağda yer verilmemektedir. Facebook ağında hikâyemiz bölümünde "bankamızla ilgili tüm ürün ve hizmetleri www.ziraatbank.com.tr adresinden takip edebilir, soru, öneri ve şikâyetleriniz için günün her saati 08502200000 no.lu telefon hattından Müşteri İletişim Merkezi'ne ulaşabilirsiniz” ibaresi dikkat çekmektedir.

Hiçbir sosyal ağda müşteri yorumlarına olumlu ya da olumsuz geri dönüş yapılmamaktadır.

Facebook'ta 2017 Kasım ayı içerisinde 18 paylaşım yapılmıştır. Bu her gün düzenli olarak içerik üretilmediğinin göstergesidir. Instagram’da ise 26 paylaşım yapılmıştır. Bu neredeyse her gün paylaşım yapıldığının göstergesidir. Twitter ağında ise toplam 40 tweet atılmıştır. Sadece hafta içi düzenli olarak paylaşılan “sabah stratejisi” ve "günlük ekonomi ve finans bülteni” dikkat çekmektedir.

\section{Garanti Bankası'nın kurumsal iletişim hizmetleri}

Kurumun hiçbir sosyal ağında, online bankacılığa yönlendirme ve direkt olarak e-posta erişimi bulunmamaktadır. Fakat üç sosyal ağa da mobilden erişim sağlanmaktadır.

Kurumun üç sosyal medya ağında da sosyal sorumluluk kampanyalarının aktarımı yer almaktadır. Bu paylaşımlar:

- Twitter ve Facebook, "Çocuklarımızın hayatında fark yaratan öğretmenlerimizin gelişimini destekleyen Öğretmen Akademisi Vakfı'nın kurucusu olmaktan gururluyuz.” (11.11.2017)

- Twitter, “11. kez gerçekleşecek Türkiye'nin Kadın Girişimcisi Yarışması’nda finale kalan adaylar, bugün jürimiz karşısında başarı öykülerini anlattı. 28 Kasım’da gerçekleşecek ödül töreninde, kazananlar hikâyelerini tüm Türkiye'ye duyuracak.” (14.11.2017)

- Twitter, "Ekonomi Bakanlığı ve Kagider tarafından düzenlenen 2. Kadın Girişimciler Konferansı'nda, Genel Müdür Yardımcımız Cemal Onaran, kadın girişimciliğinin bankamızdaki temel taşlarını ve kadın girişimcilere sağladığımız finansal olanakları anlattı.” (17.11.2017)

- Twitter, “Bu yıl 11.sini düzenlediğimiz Türkiye’nin Kadın Girişimcisi Yarışması sona erdi! Birbirinden başarılı kadın girişimcilerimizin yanında olmaktan gurur duyuyoruz. Kazananları tebrik ediyor ve tüm girişimci kadınlarımızın başarılarının devamını diliyoruz!” \#KGY2017 (21.11.2017)

- Facebook, "11 yıldır gurur ve mutlulukla düzenlediğimiz Türkiye'nin Kadın Girişimcisi Yarışması ödül töreni bu akşam gerçekleşecek! Tüm adaylara başarılar dileriz.” \#KGY2017 (21.11.2017)

- Twitter, "11 yıldır düzenlediğimiz Türkiye'nin Kadın Girişimcisi Yarışması ödül töreni bu akşam gerçekleşecek! Adaylara başarılar dileriz.” \#KGY2017 (28.11.2017) 
- Twitter, “CDP Su Programı'nda Global A Listesi'ne giren dünya genelindeki tek finans kuruluşu olma başarısını gösterdiğimiz için mutluyuz.” (28.11.2017)

- Twitter, “\#KGY2017 Eğitim kurumlarına, firmalara ve yurt dışında eğitim görmeye hazırlanan öğrencilere sosyal sorumluluk proje danışmanlığı yapan @ciftciece, kurucusu olduğu SosyalBen Akademi girişimiyle Türkiye’nin Kadın Sosyal Girişimcisi ödülünü kazandı!” (28.11.2017)

- Twitter, “Silor salatalık tohumunda, Türkiye ihtiyacının \%90’ını karş1layan ve gelecekte dünya çapında bir firma olmayı amaçlayan Petektar Tohum'un kurucusu Büşra Yapıcı, Türkiye'nin Yöresinde Fark Yaratan Kadın Girişimcisi ödülünü kazandı!” (28.11.2017)

- $\quad$ Twitter, “En büyük hayali, kurucusu olduğu Biolive’’ tüm biyoatıkları plastiğe çeviren büyük bir işletme haline getirmek olan Duygu Y1lmaz, Türkiye'nin Gelecek Vaat Eden Türkiye’nin Kadın Girişimci ödülünün sahibi oldu!” (28.11.2017)

- $\quad$ Twitter, “Bugüne kadar 200'den fazla formül geliştiren 1K Kimya'nın kurucusu Sevginar Baştekin, Türkiye’nin Kadın Girişimcisi ödülünü kazandı!” (28.11.2017)

- Twitter, “Bu yıl 11.sini düzenlediğimiz Türkiye’nin Kadın Girişimcisi Yarışması sona erdi! Birbirinden başarılı kadın girişimcilerimizin yanında olmaktan gurur duyuyoruz. Kazananları tebrik ediyor ve tüm girişimci kadınlarımızın başarılarının devamını diliyoruz!” \#KGY2017 (28.11.2017)

- $\quad$ Facebook, “Bu y1l 11.sini düzenlediğimiz Türkiye’nin Kadın Girişimcisi Yarışması sona erdi! Birbirinden başarılı kadın girişimcilerimizin yanında olmaktan gurur duyuyoruz. Kazananları tebrik ediyor ve tüm girişimci kadınlarımızın başarılarının devamını diliyoruz!” (28.11.2017)

- Twitter, "Bir kategori, iki birinci! Şirketlerin müşteri sadakatini ve büyümesini sağlayan çok kanallı müşteri deneyim platformu Insider girişimiyle Hande Çilingir, Türkiye’nin Kadın Girişimcisi ödülünü kazand1!” (28.11.2017)

Kurumun sosyal medya ağlarında, en fazla sosyal sorumluluk kampanyaları aktarımına dair içerik üretildiği dikkat çekmektedir. Bu paylaşımlar yapılırken yapılan sosyal sorumluluk projesi kapsamına özel hashtag oluşturulmuş ve içeriklerin çoğunda bu hashtag kullanılmıştır. Ayrıca, Garanti'nin amblemi olan yonca şekli, yonca emojisi kullanılarak pekiştirilmiştir. Bu paylaşılan içerikleri, kurumsal etkinlikler ve duyurular başlığ 1 altında incelemekte mümkündür.

Ürün ve hizmetler ile ilgili içerikler, kurumun Twitter ve Facebook ağlarında eş zamanlı ve fotoğraf ile desteklenerek yayınlanmaktadır. Ürün hakkındaki içerikler:

- Twitter, Instagram, “Düşük faiz ayağınızı yerden kesecek! Opel Insignia için \%0,88 faizle 50.000 TL kredi Garanti'de. Hemen başvurun!'(09.11.2017) 
- $\quad$ Twitter, Instagram, "Honda Civic sizi bekliyor! Garanti Taşıt Kredisi ile 24 ay vade ve \%0,85 faiz firsatından yararlanın, yeni yılda bir Honda sahibi olun. Detaylı bilgi için 444OTOM'u (444 68 66) arayın.” (23.11.2017)

Instagram'da ise Türkiye'nin en sevilen mobil bankasının Garanti Cep olduğunu duyurarak, işlemlerin kolayca yapılabileceğini ve bu konuda hizmet verdiklerini dile getirmektedir. Ayrıca, en sevilen banka olmasının sebebini takipçilerine sorarak yarışma düzenleyip, bu konu hakkında yorum yapmalarını istemektedir. Böylelikle etkileşimi arttırmayı amaçlamaktadırlar.

Finans sektörü olduğu için paylaşılan içerikler, sadece 'Hizmet' başlığı altında gerçekleştirilmiş ve Instagram'dan bu konuya dair hiçbir paylaşımda bulunulmamıştır. Ayrıca paylaşılan iki içeriğin sonuna link eklenerek daha detaylı bilgiye ulaşılması sağlanmıştır.

Belirli hedef kitleye yönelik kampanyalara ve diğer kampanyalar kategorisinde duyurumu yapılan herhangi bir içeriğe rastlanmamaktadır.

Bilgilendirme içeriği ile ilgili kurumun Facebook sayfasında, "Kadın Girişimci”" sekmesi altında girişimcilik ile ilgili bilgiler bulunmaktadır. Aynı zamanda "Garanti Pratik Cevaplar” sekmesi altında da müşterilerin sıklıkla karşılaşabileceği sorunlarla ilgili bilgilere ulaşmak mümkün olmaktadır. Ayrıca bu sekme, sık sorulan sorular başlığı altında da değerlendirilebilmektedir.

Facebook sayfasında “Garanti'ye Sor” sekmesi, Twitter'da ise "Garanti'ye Sor” adlı bir twitter hesab1 bulunmaktadır. Buralar aktif bir şekilde kullanılmakta, takipçilerin ihtiyaçlarına yönelik cevaplar ve yönlendirmeler yapılmaktadır. Bu nedenle açılan bu sekmenin ve Twitter hesabını yorumlara cevap verilmesi başlığı altında incelemek de mümkün olmaktadır.

İnsan kaynakları ile ilgili kurumun hiçbir sosyal ağında paylaşıma denk gelinmemiştir.

Şube noktalarıyla ilgili bilgiye ise sadece Facebook üzerinden oluşturulan “Konumlar” başlı̆̆ı altında, harita üzerinden şubelerin yer aldıkları konuma ulaşmak mümkün olmaktadır.

Kurumun sosyal ağlarının hiçbirinde her gün olacak şekilde düzenli içerik üretimine rastlanmamaktadir. 


\section{Diğer hizmetler}

Tablo 4. Bankaların Diğer Hizmetleri

\begin{tabular}{|l|c|c|c|c|c|c|}
\hline \multirow{2}{*}{ Diğer Hizmetler } & \multicolumn{3}{|c|}{ Ziraat Bankası } & \multicolumn{3}{|c|}{ Garanti Bankası } \\
\cline { 2 - 7 } & F & T & I & F & T & I \\
\hline $\begin{array}{l}\text { Uluslararası Para } \\
\text { Birimi }\end{array}$ & 0 & 1 & 0 & 0 & 0 & 0 \\
\hline Döviz Kurları & 0 & 1 & 0 & 0 & 0 & 0 \\
\hline $\begin{array}{l}\text { Ekonomi } \\
\text { Gündemi }\end{array}$ & 0 & 1 & 0 & 0 & 0 & 0 \\
\hline Kültür Sanat & 0 & 0 & 0 & 0 & 0 & 0 \\
\hline Kariyer İlanları & 1 & 1 & 1 & 0 & 0 & 0 \\
\hline Yararlı Bilgiler & 0 & 1 & 0 & 0 & 0 & 0 \\
\hline
\end{tabular}

\section{Ziraat Bankası'nın diğer hizmetleri}

Twitter ağı üzerinden her hafta içi düzenli olarak paylaşılan "sabah stratejisi” ekleri uluslararası para birimi, döviz kurları, günlük özet piyasa verileri gibi bilgileri içermektedir. Yine her hafta içi düzenli olarak paylaşılan “günlük ekonomi ve finans bülteni” ise döviz piyasası, faiz piyasası bilgilerini grafiklerle analiz ederek sunmaktadır. Tüm bu içerikleri yararlı bilgiler başlığı adı altında incelemek de mümkündür. Facebook ve Instagram'da ise bu bilgilere yer verilmemektedir.

Hiçbir sosyal ağda kültür sanat kategorisinde paylaşılan içeriğe rastlanmamaktadır. Ancak kurumun web sitesi üzerinden "kültür ve sanat" başlıklı bölüme ulaşmak mümkündür.

10.11.2017 tarihinde üç sosyal ağda da eş zamanlı olarak yayınlanan "Ziraat Finans Grubu işe alım mülakatları sonucu asil ve yedek olarak belirlenen adaylara ilişkin listeler yayımlanmıştır” duyurusu kariyer ilanları başlığı altında değerlendirilmektedir.

\section{Garanti Bankası'nın diğer hizmetleri}

Kurumun hiçbir sosyal ağında, uluslararası para birimine, döviz kurlarına, ekonomi gündemine, kültür sanata ve kariyer ilanları ile ilgili bilgilere rastlanmamıştır. 


\section{Sosyal ağların genel karşılaştırması}

\section{Instagram ăğ genel karşılaştırması}

Tablo 5. Bankaların Instagram Ă̆ı Karşılaştırması

\begin{tabular}{|c|c|c|}
\hline $\begin{array}{c}01.11 .2017- \\
30.11 .2017\end{array}$ & Garanti Bankası & Ziraat Bankası \\
\hline Başlangıç Hayran Sayısı & 44.041 & 107.752 \\
\hline Bitiş Hayran Sayısı & 46.316 & 110.830 \\
\hline Dönemlik Hayran Artışı & 2.275 & 3.078 \\
\hline Toplam İleti & 8 & 26 \\
\hline Toplam Beğeni & 11.172 & 45.503 \\
\hline Toplam Yorum & 1.115 & 236 \\
\hline Ortalama Etkileşim & $\% 3,7252$ & $\% 1,6328$ \\
\hline
\end{tabular}

Instagram ağına bakıldığında 2017 Kasım ayı başında Ziraat Bankası'nın hayran sayısının Garanti Bankası'nın hayran sayısından yaklaşık olarak üç kat fazla olduğu sonucuna varılmaktadır. 2017 Kasım ayı sonunda Garanti Bankası'nın hayranları 2.275 artış gösterirken Ziraat Bankası'nın hayran artışı ise 3.078' dir. Garanti Bankası 2017 Kasım ayı boyunca 8 ileti paylaşımı yaparken Ziraat Bankası 26 ileti paylaşımı yapmıştır. Garanti Bankası'nın toplam beğeni sayısı 11.121 iken Ziraat Bankası'nın ise 45.503'dür. Toplam yorum sayısı ise Garanti Bankası'nda 1.115 iken Ziraat Bankası'nda 236'dır. Buna bağlı olarak da Garanti Bankası'nda ortalama etkileşim \%3,7252 iken Ziraat Bankası'nda $\% 1,6328^{\prime}$ dir.

Ziraat Bankası'nın hayran sayısı, hayran artışı, toplam ileti ve toplam beğeni oranları Garanti Bankası'ndan görünür şekilde fazlayken toplam yorum ve ortalama etkileşim oranlarının düşük olması Ziraat Bankası'nın yapılan yorumlara cevap vermemesi ile ilişkilendirilmektedir.

\section{Facebook ăğ genel karşılaştırması}

Tablo 6. Bankaların Facebook Ăğı Karşılaştırması

\begin{tabular}{|c|c|c|}
\hline $\begin{array}{c}\text { 01.11.2017- } \\
30.11 .2017\end{array}$ & Garanti Bankası & Ziraat Bankası \\
\hline Başlangıc Hayran Sayısı & 1.746 .412 & 1.918 .993 \\
\hline Bitiş Hayran Sayısı & 1.756 .994 & 1.941 .925 \\
\hline Dönemlik Hayran Artışı & 10.582 & 22.932 \\
\hline Toplam İleti & 12 & 18 \\
\hline Toplam Beğeni & 31.583 & 65.324 \\
\hline Toplam Yorum & 1.270 & 6.166 \\
\hline Toplam Paylaşım & 2.263 & $\% 0,2674$ \\
\hline Ortalama Etkileşim & $\% 0,2053$ & \\
\hline
\end{tabular}


Facebook ağında 2017 Kasım ayı başında 1.756.994 hayran sayısına sahip olan Garanti Bankası ve 1.941.925 hayran sayısına sahip olan Ziraat Bankası'nın hayran oranları karşılaştırıldığında, Instagram ağında olduğu kadar büyük farklar ile karşılaşılmamaktadır. Dönemlik hayran artışı oranına bakıldığında 2017 Kasım ayı sonunda Ziraat Bankası'nın hayran artışının (22.932) Garanti Bankası'nın hayran artışından (10.582) yaklaşık olarak iki kat fazla olduğu sonucuna varılmaktadır. Garanti Bankası 2017 Kasım ayı boyunca 12 ileti paylaşırken, Ziraat Bankası ise 18 ileti paylaşmıştır. Hayran sayısında olduğu gibi paylaşılan ileti sayısında da Instagram ağında olduğu kadar büyük farklara rastlanmamaktadır. Dönemlik hayran artışı oranında olduğu gibi toplam beğeni sayısında da Ziraat Bankası (65.324) oranlarının Garanti Bankası (31.583) oranlarından yaklaşık olarak iki kat fazla olduğu görülmektedir. Toplam yorum sayısı oranları Instagram ağında büyük farklılık gösterirken Facebook ağında birbirine çok yakındır. Buna bağlı olarak da toplam etkileşim oranları da birbirine yakın olmaktadır. Toplam paylaşım oranı ise Garanti Bankası'nda 2.263 iken Ziraat Bankası'nda 6.274'tür.

\section{Twitter ăğ genel karşılaştırması}

Tablo 7. Bankaların Twitter Ă̆ı Karşılaştırması

\begin{tabular}{|c|c|c|}
\hline $\begin{array}{c}01.11 .2017- \\
30.11 .2017\end{array}$ & Garanti Bankası & Ziraat Bankası \\
\hline Başlangıç Takipçi Sayısı & 272.389 & 301.688 \\
\hline Bitiş Takipçi Sayısı & 275.159 & 308.159 \\
\hline Dönemlik Takipçi Artışı & 2.770 & 6.471 \\
\hline Toplam Tweet & 22 & 40 \\
\hline Toplam Beğeni & 5.085 & 15.657 \\
\hline Toplam Retweet & 681 & $\% 0,1836$ \\
\hline $\begin{array}{c}\text { Ortalama Etkileşim } \\
\text { Oranı }\end{array}$ & $\% 0,1296$ & \\
\hline
\end{tabular}

2017 Kasım ayı başında Twitter ağına bakıldığında diğer ağlarda olduğu gibi Ziraat Bankası'nın (301.688) takipçi sayısının Garanti Bankası’ndan (272.389) daha fazla olduğu görülmektedir. 2017 Kasım ayı sonunda ise Garanti Bankası 2.770 takipçi artışı gösterirken Ziraat Bankası 6.471 takipçi ile yaklaşık üç kat daha fazla artış göstermektedir. Garanti Bankası 2017 Kasım ayında 22 tweet paylaşırken Ziraat Bankası'nın 40 tweet ile iki kat fazla paylaşım yaptığı görülmektedir. Bu farklılık Ziraat Bankası'nın Twitter ağında hafta içi düzenli olarak paylaştığı sabah stratejisi ve günlük ekonomi - finans bülteninden kaynaklanmaktadır. Bunun sonucunda da Ziraat Bankası, Garanti Bankası'ndan daha fazla beğeni ve retweet sayısına ulaşmıştır. Buna rağmen Ziraat Bankası'nın diğer ağlarda olduğu gibi bu ağda da karşılıklı etkileşime kapalı olması daha az içerik üretimi yapan Garanti Bankası ile 
yakın etkileşim oranlarına sahip olmasına neden olmaktadır. Garanti Bankası, oluşturmuş olduğu @Garanti'yeSor adlı twitter hesabı ile ana twitter hesabına gelen sorulara ve yorumlara cevap vermekte gerektiği takdirde direkt mesaj yoluyla takipçileriyle iletişime geçmektedir.

\section{TARTIŞMA ve SONUÇ}

Yeni iletişim teknolojileri, sağladığı kolaylıkların yanı sıra bazı zorunlulukları da beraberinde getirmektedir. Tüm bu teknolojik yeniliklerle birlikte hedef kitlelerin de değişime uğraması kurumları en işlevsel iletişim ortamlarından biri olan sosyal ağlarda bulunmaya mecbur bırakmaktadır. Kurumlar yeni iletişim teknolojilerine uyum sağlayarak sürdürülebilir ve planlı yaklaşımlarla etkin, interaktif ilişki kurma fırsatı bulmaktadır. Kurumsal temsilciler kurumun kimliğini oluşturmak ve pekiştirmek için sosyal ağlardan yararlanmaktadır. Bu sayede kurumlar sosyal medyada bulunma süreçlerini etkin şekilde yönetip kimlikleri hakkındaki algıyı da yönetebilmektedir. Yeniliklere ve değişen hedef kitlenin beklentilerine uyum sağlayamayan kurumların ise uzun vadede başarılı olabilmeleri mümkün olmamaktadir.

Son y1llarda dijitalleşme ve yeni iletişim teknolojilerinin etkilerinin en çok hissedildiği alan finans sektörü olmuştur. Değişen hedef kitle talep ve beklentilerine hızla cevap verebilmek için dijital işlemlerde değişim ve dönüşümün öncüsü olan finans sektöründeki öncü bankaların sosyal medya kullanımına yönelik bazı araştırmalar da yapılmıştır.

2017 yılında Metin Işık, Mustafa Karaca, İlker İspir, Gül Çakı, Leman Nida Yıldırım tarafından yazılan "Sosyal Medya Platformlarının Halkla İlişkiler Amaçlı Kullanımı: Bankalar Üzerine İnceleme” başlıklı makalede Türkiye Bankalar Birliği’nin verilerine göre Türkiye'deki en büyük üç bankanın (Ziraat Bankası, İş Bankası, Garanti Bankası) resmi Facebook hesapları ele alınmıştır. Örneklem olarak seçilen bankaların Facebook hesapları Grunig ve Hunt'ın Halkla İlişkilerin Dört Modeli esas alınarak oluşturulan kodlama cetvelleriyle 1 Ağustos 2017- 1 Kasım 2017 tarihleri arasında analiz edilmiştir. Elde edilen bulgular çerçevesinde, özel banka olan Garanti Bankası'nın, incelenen diğer iki bankaya göre başta sosyal medyanın çift yönlü iletişim olanağı olmak üzere pek çok özelliğini etkin olarak kullandığı gözlemlenmiştir. Bu açıdan, özel bankaların devlet bankalarına göre Halkla İlişkilerin Dört Modeli'nden İki Yönlü Simetrik Model'in daha etkin kullanıldığı sonucuna varılabilmektedir.

2016 yılında Nagihan Tufan Yeniçıktı tarafından yazılan "Halkla İlişkiler Aracı Olarak Instagram: Sosyal Medya Kullanan 50 Şirket Üzerine Bir Araştırma” başlıklı makalede sosyal ă̆ sitesi olan Instagram'ın işletmeler açısından halkla ilişkiler aracı olarak nasıl kullanıldığının ortaya konulması amaçlanmıştır. Bu amaç doğrultusunda Ekonomist dergisi tarafından 2017 yılında açıklanan "Sosyal 
Marka 100" araştırması, araştırmanın evrenini oluştururken bu araştırma sonucunda sosyal medyayı en iyi kullanan 100 şirketten ilk 50'si araştırmanın örneklemini oluşturmaktadır. İlk 50 içinde finans sektöründen beş kurum bulunmaktadır. Bunlar sırasıyla Akbank, Denizbank, Finansbank, Garanti Bankası ve ING Bank’tır. Örneklem olarak alınan bu şirketlerin kurumsal Instagram hesaplarının bulunup bulunmadığına bakılmıştır ve Instagram hesabı olan şirketlerin ise 27.10.2015-27.11.2015 tarihleri arasındaki paylaşımlarına marka kimliği, marka farkındalığı, etkileşim, içerik ve satış özendirme özellikleri bağlamında içerik analizi gerçekleştirilmiştir. Bulgularda öne çıkan sonuçlardan birisi, bu kurumların sosyal medyayı en fazla kullanan şirketler olmasına rağmen Instagram hesaplarında Facebook ya da Twitter linklerinin olmamasıdır. Kurumların Instagram hesaplarından paylaştıkları gönderilerin içeriklerine bakıldığı zaman halkla ilişkiler amaçlı paylaşımların çok az olduğu, tanıtım ya da reklam amaçlı ürünlerin ise daha fazla olduğu belirlenmiştir. Kurumların büyük çoğunluğunun paylaşılan fotoğraf ya da videoların altına yapılan takipçi yorumlarına cevap vermediği, cevap veren küçük bir kısmın ise yorumlara açıklama getirdiği ya da kurumsal siteye yönlendirdiği sonucuna ulaşılmıştır. $\mathrm{Bu}$ durum da yine kurum ile takipçileri arasında etkileşime olanak tanıyan Instagram ağının kurumlar tarafından halkla ilişkiler amaçlı olarak etkin bir şekilde kullanılmaması ile bağdaştırılmaktadır.

Bu çalışmada sosyal medya analizleri yapan www.boomsocial.com sitesi üzerinden ulaşılan "Brands Top 100" listesindeki verilere göre ilk 10'da yer alan finans sektöründen 2 markanın (Ziraat Bankası, Garanti Bankası) örneklem alınmasıyla bankacılık sektöründe faaliyet gösteren kurumların kimliklerini sosyal medya üzerinden nasıl aktardıklarının ortaya konulması amaçlanmaktadır.

Analiz edilen iki bankaya bakıldığında, kurumsal bilgi akışı başlığı altında incelenen kurumun tarihçesi, ilkeleri, vizyonu ve misyonu iki bankanın sosyal ağlarında da genellikle eksik olarak aktarılmıştır. Ancak tüm bu bilgiler kurum kimliği açısından önem teşkil etse de sosyal medyanın yapısı dikkate alındığında bu bilgilerin hepsine yer verilmesi mümkün görülmemektedir. Yine aynı başlık altında incelenen kurumsal reklamlar, etkinlikler/duyurular, basınla ilişkiler/basın odası, ürün/hizmet bilgilerine ise tüm sosyal ağlarda genellikle yer verilmiştir.

Kullanım bilgileri ve görsel aktarımı başlığı altında incelenen kurumsal rengin kullanımı, slogan, logo/amblem, video/animasyon/gif kullanımı, sosyal ağlar kısa yol girişi, ana web site linki bilgileri ise çoğunlukla iki bankanın da sosyal ağlarında bulunmaktadır. Kurumun logosundan renklerine kadar görsel tüm ögeleri içeren bu başlık, kurum kimliğini açıklamakta yetersiz kalsa da ilk bakışta kurumu tanıtıcı bir görev üstlenmektedir. Bu sebeple doğru konumlandırılmış kullanım bilgileri ve görsel aktarımı, kurumu hedef kitleye doğru açıklarken kurum kimliğini de pekiştirmektedir. 
Kurumsal iletişim hizmetleri başlığı altında dikkat çeken bulgularda öncelikle kampanya duyurularındaki eksik bilgi aktarımı yer almaktadır. Ürün/hizmet kampanyalarının duyurumu iki bankanın da sosyal ağlarında yapılmaktadır. Buna karşın diğer kampanya duyurularına iki bankanın sosyal ağlarında da yer verilmemektedir. Tüm bu kampanya duyuruları sosyal medya üzerinden kurumsal kimlik aktarımı noktasında büyük önem taşırken kurumların bu konuda birbirlerine çok zıt konumda yer aldıkları gözlenmektedir. Ziraat Bankası sosyal sorumluluk kampanyalarının aktarımına üç sosyal ağda da yer vermezken, belirli hedef kitleye yönelik kampanya duyurularına ise üç sosyal ağda da yer vermektedir. Garanti Bankası'nda ise bu durum tam tersi olarak gözlenmektedir. Bu doğrultuda yaptığı paylaşımların büyük çoğunluğu sosyal sorumluluk kampanyalarından oluşmaktadır.

Yine kurumsal iletişim hizmetleri başlığı altında incelenen etkileşim başlığı ise dikkat çeken diğer bulgu olarak göze çarpmaktadır. Ziraat Bankası'nın sosyal medyanın en önemli özelliklerinden biri olan çift yönlü iletişim noktasında eksiklikleri olduğu gözlemlenmektedir. Garanti Bankası ise Ziraat Bankası'nın aksine kullanıcılarından gelen yorumların yaklaşık 4'te 3'üne cevap vermektedir. Bu sonuçlar çerçevesinde Ziraat Bankası'nın etkileşim oranının Garanti Bankası'nın etkileşim oranından fazla olmasına rağmen hiçbir yoruma cevap vermemesi dikkat çekmektedir. Sosyal medyanın bir diğer özelliği olan dinamizm noktasında ise bulgular her gün düzenli içerik üretimi başlığı altında incelenmektedir. Ziraat Bankası bu konuda daha etkin davranış sergilerken Garanti Bankası başta Instagram ağı olmak üzere incelenen tüm sosyal ağlarda az içerik üretimi yapmaktadır.

Diğer hizmetler başlığı altında incelenen uluslararası para birimi, döviz kurları, ekonomi gündemi, kültür sanat, kariyer ilanları ve yararlı bilgilere ise sadece Ziraat Bankası'nda ve ağırlıklı olarak Twitter ağında yer verilmektedir. Sosyal ağları zenginleştirmek ve insanların ilgisini aktif tutabilmek amacıyla bu tür paylaşımlara yer verilmesi kurumlar açısından olumlu kurumsal kimlik algısı yönetimiyle ilişkilendirilmektedir. Bu konuda Garanti Bankası'nın herhangi bir paylaşımına rastlanmamaktadır.

Sonuç olarak, finans sektörü gibi çoğunlukla dijital işlemlerin görüldüğü ve mevduat sahipleriyle de etkileşimin önemli olduğu kurumlarda, kimliğin sosyal medya üzerinden aktarımı da büyük önem taşımaktadır. Türk finans sektöründe yer alan bu iki banka özelinde yaptığımız çalışma ve sosyal medyanın yapısı dikkate alındığında, Garanti Bankası ve Ziraat Bankası'nın kurumsal kimliğini pekiştirmek için sosyal ağlardan yararlandığı görülmektedir. Bu bağlamda, iki bankanın sosyal medyada bulunma süreçlerini etkin şekilde yönetip kimlikleri hakkındaki algıyı da yönettiğini söylemek mümkündür. 
Alanda yapılan literatür taramasında, bankalar özelinde birebir benzer bir çalışma ortaya konulmamış olması çalışmayı özgün kılmaktadır. Buna karşın, çalışmada sadece Kasım 2017 verilerinin kullanılması ve yalnızca iki bankaya yer verilmesi çalışmanın önemli bir sınırlılığı olarak görülmektedir. $\mathrm{Bu}$ açıdan, gelecek çalışmalarda çalışmada kullanılacak verilerin zaman diliminin genişletilmesi ve uluslararası diğer bankaların da çalışmaya dâhil edilmesinin alana büyük katkı sağlayacağı düşünülmektedir. 


\section{KAYNAKÇA}

Akıncı Vural, Z. B. - Bat, M. (2013). Teoriden Pratiğe Kurumsal İletişim. İstanbul: İletişim Yayınları.

Akıncı Vural, Z. B. - Bat, M. (2014). Yeni Bir Medya Olarak Sosyal Medyanın Genel Çerçevesi. Dijital Panorama Bilgi İletişim Teknolojilerinde Son Gündem. Ed. Akıncı Vural Z. B. Ankara: Ütopya Yayınevi.

Akıncı Vural, Z. B. - Kesken, R. (2012). Rekabet Avantajı Sağlanmasında Kurumsal Pazarlama ve Kurumsal Görsel Kimlik. Erciyes İletişim Dergisi. 2 (4), 54-74.

Akıncı Vural, Z. B. (1998). Kurum Kültürü ve Örgütsel İletişim, İstanbul: İletişim Yayınları.

Alton Y.K Chua, Snehasish Banerjee, (2013). Customer Knowledge Management via Social Media: The Case of Starbucks. Journal of Knowledge Management. 17(2), 237-249.

Arıkan, A. (2017). Kurumsal Tasarım ve Görsel Kimlik: Kurumsal İletişim. Ed. Başak Solmaz. Eskişehir: Anadolu Üniversitesi Basımevi.

Atam, A. A. (2014). Kurumsal Kimlik Çalışmaları: Beko Örneği. The Turkish Online Journal of Design, Art and Communication. 4 (2), 16-39.

Aydın, A. F. (2012). Kurumsal İtibar Açısından Sosyal Medyaya İlişkin Değerlendirme. Karadeniz Teknik Üniversitesi İletişim Araştırma Dergisi. (9), 78-92.

Azzollini, M. (2016). What is Corporate Identity and Why is it Important? https://www.linkedin.com/pulse/what-corporate-identity-why-important-meenaazzollini. Erişim Tarihi: 05.11.2017.

Baskan Karsak, B. (2008). Web Sitelerinin Kurumsal Kimlik Açısından Değerlendirilmesi: En Beğenilen 20 Şirket Üzerine Bir Analiz. İleti-ş-im. Sayı:9, 165-179.

Carr, C. T. - Hayes, R. A. (2015). Social Media: Defining, Developing, and Divining. Atlantic Journal of Communication. 23(1), 46-65.

Castronovo, C. - Huang, L. (2012). Social Media in an Alternative Marketing Communication Model. North American Business Press. 6(1), 117-134.

Edosomwan, S. - Kalangot Prakasan, S. - Kouame, D. - Watson, J. - Seymour, T. (2011). The History of Social Media and its Impact on Business. The Journal of Applied Management and Entrepreneurship. 16(13), 79-91.

Er, T. (2016). Kurumsal Kimlik Oluşumunda Kültürün Etkisi; Arçelik’in Kurum Kimliği. Yayınlanmamış Yüksek Lisans Tezi. İstanbul: T.C İstanbul Arel Üniversitesi Medya ve Kültürel Çalışmalar Anabilim Dalı. 
Erdem, O. - Dikici, M. (2009). Liderlik ve Kurum Kültürü Etkileşimi. Elektronik Sosyal Bilimler Dergisi. 8 (29), 198-213.

Güçdemir, Y. (2017). Sosyal Medya Halkla İlişkiler, Reklam ve Pazarlama. İstanbul: Derin Yayınları.

Hearn, G. - Foth, M. - Gray, H. (2009). Applications and Implementations of New Media in Corporate Communications: An Action Research Approach. Corporate Communications: An International Journal. 14(1), 49-61.

Hepkon, Z. (2003). Kurumsal Kimlik İnşasını Belirleyen Faktörler: Bir Literatür Taraması. İstanbul Ticaret Üniversitesi Dergisi. Sayı:9, 175-211.

İnce, M. E. Kurumsal Kimlik. http://www.kto.org.tr/d/file/kurumsal-kimlik.pdf. Erişim Tarihi: 19.11.2017.

Jefkins, F. (1995). Kurum Kimliği. Çev: Okay Aydetmir. Marmara İletişim Dergisi. Say1:9, 33-40.

Karadeniz, M. (2009). The Importance of Creating a Successful Corporate Identity and Corporate Image for Enterprises in Marketing Management. Journal of Naval Science and Engineering. 5 (3), 1-15.

Karatepe, S. (2008). İtibar Yönetimi: Halkla İlişkilerde Güven Yaratma. Elektronik Sosyal Bilimler Dergisi. 7 (23), 77-97.

Kaya, F. B. Ü. (2006). Kurum Kimliği ve Kurumsal Tasarım. Tasarım+Kuram Dergisi. Say1:4, 27-37.

Mavnacioğlu, K. (2015). Kurumsal İletişimde Sosyal Medya Yönetimi Kurumsal Blog Odaklı Bir Yaklaşım. Istanbul: Beta.

Mayfield, A. (2008). What is Social Media?.

http://www.icrossing.com/uk/sites/default/files_uk/insight_pdf_files/What\%20i

\%20Social\%20Media_iCrossing_ebook.pdf. Erişim Tarihi: 31.10.2017.

O'Reilly, T. (2007). What Is Web 2.0: Design Patterns and Business Models fort he Next Generation of Software. International Journal of Digital Economics, 65(1), 17-37.

Olins, W. (2003). Corporate Identity: The Myth and The Reality: Revealing the Corporation. Ed. John M. T. Balmer, Stephen A. Greyser. Londra: Routledge.

Onat, F. - Aşman Alikılıç, Ö. (2008). Sosyal Ağ Sitelerinin Reklam ve Halkla İlişkiler Ortamları Olarak Değerlendirilmesi. Journal of Yasar University. 3(9), 1111-1143.

Özdemir Çakır, H. (2016). Sosyal Medyada Kurumsal İtibar Yönetimi, İstanbul: Kriter Yayınevi.

Özel, E. K. (2014). Çalışanların Twitter Kullanımının Kurum İmajına Etkisi: Türkiye'de Bir Anket Çalışması. Journal of Yasar University. 9(35), 6138-6158. 
Öztürk, G. (2006). Logonun Kurum Kimliği Üzerindeki Etkisi. İstanbul Ticaret Üniversitesi Sosyal Bilimler Dergisi. 2(5), 1-17.

Öztürk, G. (2006). Logonun Kurum Kimliği Üzerindeki Etkisi. İstanbul Ticaret Üniversitesi Sosyal Bilimler Dergisi. 5 (9), 1-17.

Pempek, T. A. - Yermolayeva, Y. A. - Calvert, S. L. (2009). College Students' Social Networking Experiences on Facebook. Journal of Applied Developmental Psychology. 30(6), 227-238.

Roshan, M. - Warren, M. - Carr, R. (2016), Understanding the Use of Social Media by Organisations for Crisis Communication. Computers in Humor Behavior. (63), 350-361.

Roshan, M. - Warren, M. - Carr, R. (2016). Understanding The Use of Social Media By Organisations For Crisis Communication. Computers in Humor Behavior. 63, 350361.

Sezgin, M. K. (2008). İletişim Biçimi ve Ortamı Olarak Görsel Kimlik. Selçuk İletişim. 5 (2), 61-67.

Telli Yamamoto, G. - Karamanlı Şekeroğlu, Ö. (2014). Sosyal Medya ve Blog, İstanbul: Kriter Yayınevi.

Tığlı, M. (2003). Kurum İmajı Kavramı ve Sembolik Anoloji Tekniği Yoluyla Marmara Üniversitesi’nin Kurum İmajının Belirlenmesine İlişkin Bir Uygulama. T.C Marmara Üniversitesi İ.İ.B.F. Dergisi. XVIII (1), 245-256.

Tokatlı, M. - Özbükerci, İ. - Günay, N. - Akıncı Vural, Z. B. (2017) Kurumsal İtibarın Sosyal Medya Üzerinden Aktarımı: Sektör Liderlerinin Twitter Yönetimi Üzerine Bir Araştırma. Gümüşhane Üniversitesi İletişim Fakültesi Elektronik Dergisi. 5(1), 34-57.

Uzoğlu, S. (2001). Kurumsal Kimlik, Kurumsal Kültür ve Kurumsal İmaj. Kurgu Dergisi. Sayı:18, 337-353.

What is Corporate Identity and Why Is It Important?, https://www.treefrog.ca/what-iscorporate-identity. Erişim Tarihi: 14.11.2017. 